Journal of Southeast Asian

\title{
Articulating Refug-endity in VietnAmerica and the Diasporas 1975-2015: From Ethnic Autonomy to Global Visibility
}

Trangdai Glassey-Tranguyen

Founder \& Director, Vietnamese Diasporas Projects, vietamproj@gmail.com

Follow this and additional works at: https://docs.lib.purdue.edu/jsaaea

Part of the Race, Ethnicity and Post-Colonial Studies Commons, and the South and Southeast Asian Languages and Societies Commons

\section{Recommended Citation}

Glassey-Tranguyen, Trangdai (2015) "Articulating Refug-endity in VietnAmerica and the Diasporas 1975-2015: From Ethnic Autonomy to Global Visibility," Journal of Southeast Asian American Education and Advancement. Vol. 10 : Iss. 1, Article 5.

DOI: $10.7771 / 2153-8999.1120$

Available at: https://docs.lib.purdue.edu/jsaaea/vol10/iss1/5

This document has been made available through Purdue e-Pubs, a service of the Purdue University Libraries. Please contact epubs@purdue.edu for additional information.

This is an Open Access journal. This means that it uses a funding model that does not charge readers or their institutions for access. Readers may freely read, download, copy, distribute, print, search, or link to the full texts of articles. This journal is covered under the CC BY-NC-ND license. 


\title{
ISAAEA, Journal of Southeast Asian American
Education and Advancement
}

Volume $10(2015)$

WWW.JSAAEA.org

\section{Articulating Refug-endity in VietnAmerica and the Diasporas 1975-2015: From Ethnic Autonomy to Global Visibility}

\author{
Trangdai Glassey-Tranguyen
}

KEYWORDS: refug-endity, VietnAmerica, diasporas, ethnic autonomy, global visibility, oral history narratives, ethnographic fieldwork, intergenerational dynamics, Vietnamese language, the politics of memories and remembrance, Vietnam War, Geneva Accord, freedom, boat people experiences, Vietnamese gulags or concentration camps, French colonialism, dislocation/ resettlement, concept of home, historical/personal/political self, gender/race/ethnicity, memory, PTSD, 1.5ers.

\begin{abstract}
Since the culmination of the Vietnam War on April $30^{\text {th }}$, 1975, waves of Vietnamese evacuees, refugees, and immigrants arrived in the United States and created a new home across the country. Orange County, California, is home to the largest concentration of Vietnamese Americans since 1975 in the U.S., and has notoriously been known as the "Vietnamese refugee capitol" in the diasporas. I argue that there has been an organic, thriving - albeit very under-studied - body of Vietnamese-language literature and media in Orange County and VietnAmerica since 1975, which provides a fertile ground for the articulation of what I call "refug-endity." These Vietnamese-language publications and cultural productions are highly autonomous yet hidden from the mainstream owing to cultural and language barriers. Nonetheless, I suggest that this refug-endity despite its seeming isolation - has a dormant yet permeating life, and is continued through the works of ethnic-Vietnamese artists of diasporic generations. Forty years later, refug-endity has evolved from ethnic autonomy to global visibility, with new diasporic crops in the making and a flourishing resurgence of the ethnic language in the American mainstream as well as within the ethnic enclaves. This entry draws from my research as well as lived experiences of nineteen years in Vietnam, as well as over two decades in Orange County and several parts of the Vietnamese diasporas worldwide. In particular, this article is based on my organic knowledge of, academic studies of, and contributions to the development of Vietnamese archives, media and cultural production, and primary sources in the Orange County (and beyond) ethnic enclave over the past forty years. Through
\end{abstract}

\section{$\circledast$}

SORERIEHISRESEREEDReaders are free to copy, display, and distribute this article, as long as the work is attributed to the author(s) and the Journal of Southeast Asian American Education \& Advancement, it is distributed for non-commercial purposes only, and no alteration or transformation is made in the work. More details of this Creative Commons license are available at http://creativecommons.org/licenses/by-nc-nd/3.0/. All other uses must be approved by the author(s) or JSAAEA.

Journal of Southeast Asian American Education \& Advancement, Vol. 10 (2015) ISSN: 2153-8999 
Trangdai Glassey-Tranguyen- Articulating Refug-endity in VietnAmerica and the Diasporas

analysis of works and programs pertaining to refug-endity, I reflect on four decades of the Vietnamese language productions, the themes of these productions, and the political economy that allowed for these productions to have life.

\section{INTRODUCTION}

Forty years into the making of the Vietnamese diasporas, generations of ethnic Vietnamese artists have committed to their creative call and dedicated to documenting their experiences through the arts, and by so doing have helped to continue the expression of, the search for, and the honoring of the Vietnamese diasporic experience - a legacy that will be passed on to future generations as to help keep them connected to their roots.

\section{SIGNIFICANCE}

This article aims at providing an overview and analysis of what I call "refug-endity" in VietnAmerica and the diasporas from 1975 to 2015. The paper begins by arguing for and examining the refugee generations' autonomy in creative expressions, and concludes with the global visibility of diasporic-generations' artistic works. Given the deep-seated theme of refugee and immigrant experiences that stem from the Vietnam War, I argue that there is a crossgenerational continuation of Vietnamese diasporic refug-endity albeit the language negotiations and inter-generational differences. The article contributes to an understanding of the Vietnamese diasporic arts and letters, with a focus on the articulation of refugee identities and its intergenerational dynamics. The primary data published for the first time in English in this entry, the oral history narrative excerpts drawn from two decades of multi-sited research, as well as the English translations of relevant Vietnamese texts, will make unparalleled contributions to the topic at hand and beyond. Most importantly, this article will bridge the gap between the English and diasporic Vietnamese literatures, and between academia and the larger (as well as ethnic) readership owing to its accessibility, groundedness, and inclusive approach.

\section{OVERVIEW}

In this entry ${ }^{\mathrm{i}}$, I begin by exploring the literature that is written by Vietnamese Americans and is published primarily in Vietnamese since 1975 in the diasporas. I argue that this body of texts is hidden from and inaccessible to the American public and academic readership, and as a result is unknown in general and uncited in English scholarship. Yet this thriving literary corpus has provided important contributions to the expression, documentation, and understanding of the Vietnamese American experiences, particularly the Vietnam War from the Vietnamese perspectives, its aftermath, and the making of VietnAmerica. (VietnAmerica is a term ${ }^{\mathrm{ii}} \mathrm{I}$ have used since the 1990s to refer to Vietnamese America with an emphasis on its interbeing with pan-ethnic United States, its hybridity, and its transnational identity.) As such, this autonomous body of works - with a certain level of intra-ethnic tension and contestation ${ }^{\text {iii }}$ - forge what I call refug-endity, which reflects the experiences and perspectives of ethnic Vietnamese in the U.S., and is independent of and even different from the partial or systemic concept of the "refugee" found in "refugee literature" of mainstream America or academia. 
Trangdai Glassey-Tranguyen- Articulating Refug-endity in VietnAmerica and the Diasporas

This entry focuses on the much-needed yet very under-studied Vietnamese-language publications and cultural productions in Vietnamese America and diasporas, and is grounded in my participation in and studies of these practices since the early 1990s. My conceptualization and argument are grounded in these organic knowledge and contributions. To this aim, and given the constraints of this article, I will not be engaging with related scholarships and intend to do so in follow-up publications. In response to the lack of cross-lingual work that connects the Vietnamese- language literature with English readers, this entry will reflect on the Vietnamese language production over the last forty years, the themes of these productions, and the political economy that allowed for these productions to have life.

From the late-1970s through the mid-1990s, print publications of works by Vietnamese refugees proliferate, especially in Orange County, California. These publications are both new and old - written and published pre and post-1975 - by those who have immigrated to the U.S. or elsewhere, as well as by those still struggling to escape from Vietnam. This entry does not aim at providing a survey of this body of literature, but rather to explore its role in the psyche and experiences of Vietnamese Americans by looking at some relevant texts ${ }^{\text {iv }}$ and engaging with a broad range of topics and writers that pertain to the entry's theme. With the boom of online media in the early 2000s that follows the 1997 .com bubble, new literature sites and zines flourish, and further connect ethnic Vietnamese writers and readers from around the world. The literary world in VietnAmerica, while already having a leading role in the Vietnamese diasporas, has inherently become more global with cyberspace. Today, ethnic literature in the Vietnamese diasporas is diverse and multilingual, with the Vietnamese language - though no longer playing the absolute role - still remaining a cultural reference point and a source of inspiration.

By way of conclusion, I shift my focus toward the global young Vietnamese-diasporic artists and writers who primarily use non-Vietnamese languages and how they grapple with their ethnic language, either by making use of it in their works or revering it as sacred and leaving it alone. Regardless of the variegated approaches, the younger generations show a very nuanced and/or direct continuation of the refugee experiences, and with or without intention, pay tribute to the refugee-generation writers whose works form the initial definitions of what a refug-endity might look like in VietnAmerica and the world over. This continuation speaks eloquently of the generational dynamics of refugee literature, unlike the disruption and binary between refugee and diasporic generations maintained in traditional scholarship. Here, I argue for a much more complex straddling across generational lines of diasporic ethnic-Vietnamese artists who through asking questions about their past and heritage have taken an active role in providing possibilities for new and renewed definitions of refug-endity. With a mindfulness of this inter-generationality, the entry brings together for the first time the creative works of ethnic-Vietnamese in the diasporas from various generations and in different languages and/or genres, and juxtaposes voices that might have existed independently to show their connectedness. Forty years into the making of the Vietnamese diasporas, generations of ethnic Vietnamese artists have committed to their creative call and dedicated to documenting their experiences through the arts, and by so doing have helped to continue the expression of, the search for, and the honoring of the Vietnamese diasporic experience - a legacy that will be passed on to future generations as to help keep them connected to their roots.

Of the diasporic-generation artists who came of age after the Vietnam War ended, I cite those working on and beside the literary meadows - those traditionally defined as literary persons such as poets, and those working in the visual and performing arts. I deem that this 
Trangdai Glassey-Tranguyen- Articulating Refug-endity in VietnAmerica and the Diasporas

stance is particularly apt in today's multi-media cross-genre society, where the inter-genre boundaries are constantly pushed, made productive, and transcended. These artists are the new waves of Vietnamese diasporic literati who prominently figure their Vietnamese heritage in their works, a heritage that both informs their arts and is in turn shaped by their new interpretations. Their works offer a different kind of "literature" that proffers visual and metaphorical readings of texts and contexts pertaining to Vietnam's history and its remnants. As such, these bodies of visual and performing arts speak directly of and from archival materials, making use of both the artifacts and texts from Vietnam's past and their implications in the diasporas. In this sense, "refugee literature" as a genre is not confined to those works that pertain primarily to the letters alone, but all that speak of the texts and contexts of Vietnam, its diasporas, and their relationship to the rest of the world. More importantly, these works suggest new ways of looking at the refugee figures and engaging with the refugee cultural production on the global arena, illuminating ethnic-Vietnamese aurality and perspectives of the Vietnam War and other historical events that have been thus far either silent or relegated to the background in Westernoriented historiography.

This entry draws from the multi-sited longitudinal projects I have conducted in the Vietnamese diasporas since 1994, including the award-winning Vietnamese American Project, the Vietnamese Stockholm Project under a Fulbright full grant, the Vietnamese Berlin Project, and others. These multi-genre projects wed cross-lingual oral history methodology, decades-long ethnographic fieldwork, community participation, and cross-disciplinary analysis. The entry includes unpublished primary data from my interviews and critiques formerly published in Vietnamese, as well as English translations of original texts in Vietnamese. I compose the critiques on forthcoming books and art exhibits upon invitations from the editor/author and curator. The critiques are syndicated in various publications both in print and online across the diasporas such as Gió O, Diễn Đàn Thế Kỷ, Thư Viện Sáng Tạo, Da Màu, Trí Nhân Media, Tương Tri, Sống Weekly, Trẻ Weekly (Texas), Người Việt Daily, Việt Báo Daily, Viễn Đông Daily, Hiệp Nhất, Diễn Đàn Giáo Dân, Thư Viện Hoa Sen, and several others.

I would like to note that throughout this entry as well as in my research in the last two decades, I privilege the voices and perspectives of ethnic Vietnamese writers and artists and treat them as both data and theories. That is, with these voices and perspectives situated at the center of the discussion, the Vietnamese refugee aesthetics reveals its innate autonomy, agency, and self-determination from the inception.

\section{REFUG-ENDITY DEFINED}

This section aims at providing a historical contour of refug-endity as the background for the entry. The primary quotes herein come from translated literary works; some are oral history excerpts to privilege the first-person perspectives and to honor the various forms of expression. Though the influx of Vietnamese refugees came about in 1975, the presence of this ethnic group in America dates much further back. Since the 1950s, international diplomacy and educational exchange had brought different groups of Vietnamese to the United States, where many of them remained after the Fall of Saigon. Cultural contact, however, traces much further back. For ethnic Vietnamese, refug-endity did not emerge with the 1975 Fall of Saigon when the Vietnamese people left their home country in unprecedented numbers, but much earlier than that and while they were still in Vietnam (Glassey-Tranguyen, 2014a). Though the refugee 
Trangdai Glassey-Tranguyen- Articulating Refug-endity in VietnAmerica and the Diasporas

experiences of the Vietnamese people (or any others) date back hundreds of years, in the context of this paper, I will only mention the period from the twentieth century till today for its immediate relevance to the topic at hand. Vietnamese were already refugees in their own homeland with the 1954 Southward migration, the 1968 Tết Offensive evacuation and relocation, among other events during the French colonial period and the Vietnam War. Owing to the Vietnamese cultural sense of attachment to the hometown, those living away from home in Vietnam would describe themselves as living in "một cảnh hai quê" ("one life but two homes," my translation). This situation is similar to the split family in the global world where emigrants earn a living for their family back in the home country.

In the personal history narratives I gathered since the 1990s of Vietnamese Americans and their counterparts around the world, the theme of dislocation and relocation was omnipresent. As I have argued elsewhere, the meta-events - such as the 1954 Geneva Accord and the subsequent Southward migration of millions of Northern Vietnamese - mask the multidirectional and much more complicated trends of migration in twentieth-century Vietnam (Tranguyen, 2004a; Glassey-Tranguyen, 2015). For instance, in the 1940s-1950s, Vietnam was at the height of chaos, simultaneously confronting the French colonial demise, Japanese occupation, and anticipated American involvement. Beyond economic adversity, war atrocities were a common part of life. The uncertainty of Vietnam's nation status was reflected in the lives of its citizens. Even children experienced death up close, observing unattended corpses on the roads and witnessing family members being killed in raids. Nghiêm Đại Đạo (GlasseyTranguyen \& Nghiêm, 2000), a surgeon at the University of Pittsburgh Hospital, recalled his family's constant movements during his early years in a biographical oral history interview ${ }^{\mathrm{v}}$ :

... In 1945, when the Japanese were invading Vietnam or Indochina at the time, we went back to Hà Nội from Cambodia by boat to go faster. We stayed in our birth house, about ten kilometers from the non-controlled French area. There was no school. My Dad and sister taught me as much as they could. But my Dad was killed by the French when they raided us in 1948. I was only seven years old.

The year 1954, however, brought the most perturbing event of all. The Geneva Accord was signed on July 20 and divided Vietnam with the provisional demarcation line at the 17 th parallel. The Vietnamese psyche was deeply troubled beyond reacting to its immediate impacts. The Communist Party took over the North, and the Republic of South Vietnam was established in the South. Vietnamese in the North were to decide whether to stay or migrate southward. Some two million had gone south. The separation and uprooting of hundreds of thousands of families and of millions of Northerners still plagues the depth of their everyday existence. Many families are still living apart today and have never been reunited. Robert Nghiêm Nguyễn (Glassey-Tranguyen \& Nguyễn, 2000), who holds an MA in anthropology and is a VAP narrator, took to heart his mother's words on the way South:

Ạ à ơi, ạ ời ời

I carry you on my shoulders, I hold you in my arms

I do not mind this strenuous southward migration

My child, take this to heart: 
Trangdai Glassey-Tranguyen- Articulating Refug-endity in VietnAmerica and the Diasporas

Keep your Vietnamese spirit when you grow up

Connect our country, make it one body

Protect the land, preserve its identity

This poem (my translation) won the national prize in poetry in 1955 (Glassey-Tranguyen \& Nguyễn, 2000) and was regularly sung on the radio in the Republic of South Vietnam for its power to capture the immediacy of the time. While the 1954 Rivervine Division scattered national oneness and triggered desire and determination for unity, the Vietnam War worsened the conditions of civilian life in war zones nationwide, extending the blades of destruction upon nonmilitary areas. The 1968 Tết Offensive was an unexpected and devastating assault on the Republic of South Vietnam and its people. This is arguably the second major event, following the 1954 Southward migration, that displaced so many civilians during this time period. The U.S. government's records categorize Vietnamese displaced by the 1968 Têt Offensive as "refugees,"vi and works by Vietnamese writers such as the famed female author Nhã Ca's Giải Khăn Sô cho Huếvii reflect the atrocities, sufferings, and desperation on the ground. The book remains a primary reference for Vietnamese Americans on the Offensive, and has been made available in English in August 2014.

I argue that given this long history of relocation and displacement in their own home country in the twentieth century, ethnic Vietnamese have already forged and articulated a "refugendity" by the time the Fall of Saigon occurred in April 1975. However, the magnitude and abruptness of the Fall and of the subsequent evacuations brought this refug-endity to the international level with climactic chaos and disorientation. The tumultuous exodus comes with a deep sense of loss: loss of one's personal past, home, family, and country. Vietnamese leaving the country starting in 1975 thought that they would never be able to return to their homeland again. This is possibly the greatest sense of loss owing to the Vietnamese cultural sense of attachment to the motherland, their ancestral hometown, and their loved ones. This is a new moment and a decisive turn in Vietnamese refug-endity. The Vietnamese refugee bodies are now displaced outside of Vietnam, unlike in 1954 or 1968, and the Vietnamese cultural identity is challenged and clashed against the hosting Western world. The clash is much greater than the cultural negotiation during the French colonization and the American influence because when these events take place in Vietnam, there is a strong anti-foreign resistance despite the inherent adaptations. When the Vietnamese bodies enter the Western world and are outside of their home country, they are faced with the pressure to assimilate and acculturate to the host society. Though the Vietnamese refugees' determination and efforts to preserve their root culture have yielded great fruits after four decades, the mainstream culture is no longer that of Vietnamese. One can argue that in some places-like Orange County's Little Saigon-the Vietnamese culture is dominant. Not quite - it is rather the Vietnamese American culture, which is a "refugee" culture, an ethnic sub-culture. Hence, such places are still under the host country's governance and the Vietnamese ethnic community still serves primarily the respective constituents albeit with apparent cross-ethnic interactions.

As such, in 1975, refug-endity takes on a new meaning and a different level of displacement for Vietnamese who are now truly away from home. I argue that the sense of permanent separation from their homeland brings the greatest pain of all, for it includes the refugees' separation from loved ones left behind and from their hometowns that hold their personal history. Nonetheless, I see the previous dislocations of 1954 and 1968 as the fomenting 
Trangdai Glassey-Tranguyen- Articulating Refug-endity in VietnAmerica and the Diasporas

grounds for the 1975 departures, and as the reference points which several Vietnamese hark back to, particularly with the Southward migration. In that sense, there is a continuation of refugendity that starts inside Vietnam during the early twentieth century and expands outward in 1975. From the 1954 North-South division to the 1975 shattering of South Vietnam, the Vietnamese psyche was mediated at two levels: national and international. If those leaving the North in 1954 had mourned the separation before they even went South, the Vietnamese refugees in April 1975 must have felt such an agonizing valediction leaving home in such great pain and abruptness.

Recalling the interval pre- and post-1975 in Vietnam opens up wounds that remain unhealed. When the U.S. army withdrew from Saigon, leaving the South to the control of Communist authority, many who had left the North in 1954 were the first to leave the country, having experienced the cruelty of this political force. The unexpected, abrupt departure in 1975 left many in shock, even long after the evacuation. Some left before the fall of Saigon, however, through American employers' arrangement, with no less degree of disbelief. Thiênnữ Vũ (Glassey-Tranguyen \& Vũ, 2000), a professor of medicine at the University of California, San Francisco, and Head of the Lung Biology Center at San Francisco General Hospital, relates,

. . . My family left on the 23rd of April, 1975. At the time, my Dad worked for Bank of America who told us to ready ourselves to leave the country any minute. But we never thought that it would happen. When we were actually leaving for America, my Mom got very worried because it's a big deal for my parents with six kids to leave home for a new country, not speaking the language, not knowing what would happen.

Many were left behind, however, to face the consequences of a post-war country and undergo sociopolitical persecution. The Communist regime persecuted and imprisoned professionals, artists, religious leaders, and former military personnel of the Republic of South Vietnam in what the new rulers euphemistically call "reeducation camps." The camps are the equivalent to the concentration camps of the Holocaust in their schemes of human degradation and annihilation. The political despotism further pushed millions of Vietnamese to flee the country, starting with the boat people in the late 1970s, who instantaneously captured international attention and sympathy. Others traveled by foot to neighboring nations such as Laos, Thailand, and Cambodia, seeking asylum in a third country. The catastrophes on land or at sea were fatal, keeping the refugees on the brink of death and assaults. Paul Nguyễn (GlasseyTranguyen \& Nguyễn, 2000b) associated his mother and sisters' escape on foot to Cambodia with being constantly on guard against robbers and military attacks. People escaping by boat, furthermore, were at the risk of inadequate boarding space, inclement weather, lack of food, and Thai pirates. More than half of the boat people drowned in the ocean. Many women were raped and captured by Thai pirates, remaining as disappeared members of the Vietnamese diasporas. Ann Phong of Cerritos (Glassey-Tranguyen \& Phong, 2000), an eminent artist with innovative themes and styles, spent years after her escape processing the desperation at sea and postsurvival depression. Phong used art as a therapeutic method to release her anger as well as asserting her identity (Glassey-Tranguyen, 2011a),

... Living in the refugee camp, listening to the Vietnamese women who were raped and robbed, was a down point of my life. They still influence me today in my art. The rape, 
Trangdai Glassey-Tranguyen- Articulating Refug-endity in VietnAmerica and the Diasporas

the robbing, the darkness of the ocean. Because after four days and nights when I went up to the shore, there was no moon, no stars, nothing. To look at the ocean was so scary. You saw black.

Until 1986, all Vietnamese refugees had automatic admission to a third country. Not all refugees were granted admission thereafter, however. Many were forced to repatriate, and several committed suicide, repeating the motto of those who left Vietnam at all costs, "Death rather than Red." Others led a marginal, undocumented life in self-sufficient camps. When the United Nations High Commission for Refugees (UNHCR) halted the refugee programs in Southeast Asia in 1996, approximately 2,000 Vietnamese in the Philippines were declared stateless, gaining sympathy and advocacy for resettlement from the diasporic population. The 2,000 are members of separated families, who immediately responded to the call for political voices and support. Until today, many Vietnamese refugees are still in migration limbo and remain unsettled or stateless for life. Vietnamese refug-endity, therefore, remains a complex and open-ended reality in today's global contexts.

The exodus in 1975 and subsequent waves of refugees have brought to fruition a fuller understanding of Vietnamese ethnicity and a greater awareness of the Vietnamese self as an individual within the world community as Vietnamese refugees were dispersed around the world. In the U.S., they were first placed in refugee camps, such as Camp Pendleton in San Diego, before being relocated to a city - granted sponsorship by an American family or a faith-based institution. Given their war and migration experiences, new arrivals faced post-traumatic stress disorder, feeling both the loss of home, country, family, and self. The crude reality of refugee camps hit hard, revealing an inmate's feelings of being abased, of being less than human, as poet Du Tử Lê (Glassey-Tranguyen \& Du Tử Lê, 2002) delineated in the following excerpt (Du Tử Lê, 1987) (my translation):

\author{
thank you \\ thank you Pendleton \\ for the tent \\ I creep in and out \\ uncertain and hesitating \\ like a yellow rat \\ with a frozen mind \\ and useless hands
}

I ask, then: How do the 1954 Southward migration experiences and nostalgia chime with the sentiments of the 1975 exodus? Through the juxtaposition of a work about the 1954 Southward migration with one about the 1975 exodus, one can discern the continuum in which the figure of the refugee is conceptualized, expressed, and analyzed. The famed late Mai Thảo's

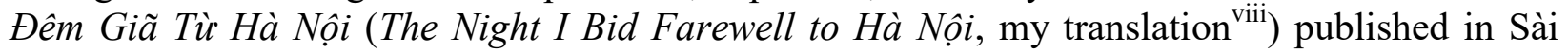
Gòn in 1955 by Người Việt, has been republished and revisited widely in VietnAmerica for its expression of agony in parting with one's home and one's hometown - both are very sacred in the Vietnamese cultural psyche. Mai Thảo leaves Hà Nội in 1954 when Vietnam is divided at Parallel 17, after his contributions to the French-resistance movement for national independence 
Trangdai Glassey-Tranguyen- Articulating Refug-endity in VietnAmerica and the Diasporas

since 1948. His choice to go South is clear and decisive, a departure from a past and all of the deceptions that come with it. He writes (my translation):

Phượng looks down at the pit.

Hà Nội is down there.

From where he stands, Phượng looks across the street. The boulders of darkness have gelled together. The roofs of Hà Nội fade away, one by one. Phượng looks up to that row of old, sickly roofs; in a blurry moment, he feels that they hold so many heartaches, so many deep thoughts. The silenced heart's talks. The oppressed concerns. Those of Hà Nội's. And those of his, too.

Under the curved concaving roofs laden with the seasonal leaves are modes and changes that Phượng couldn't fathom. Hà Nội is changing color. Looking over from this side of the street, Phượng starts to feel a sort of shivering; he has already stood on one side of the parallel, looking at the other side. On that side, there are images of brokenness, of disruptions. On that side, there are the forts, the barbed wire, the forbidden roads, the sans-people areas. Phượng did not understand why. At this very moment, he still belongs to Hà Nội, breathing with it, living its pains, but Hà Nội is somehow already on the other side.

Mai Thảo articulates the psyche of a refugee who has not left his place of origin yet feeling all the alienation and distance from it. His sense of disbelonging to Hà Nội is many fold, but the difference in political orientation is most prominent. He writes, also in the same short story about leaving Hà Nội ${ }^{\text {ix }}$ (my translation),

Standing by himself in the long night, in front of a Hà Nội sound asleep, Phượng thought of the friends who have crossed Hồng Hà River, have left Hà Nội behind, have departed from the Northern land before him, crossing the parallel to continue the fight for freedom, for humankind, in the other part of his country. He knows that this era will connect human beings with an idea and system of freedom. Phượg's psyche tonight is also the psyche of a German mechanic, a Korean farmer, who are day and night crossing over the parallels of bondage to seek a new direction, a horizon with air and light.

This political orientation of choosing freedom over dictatorship is shared by all who went South in 1954, as well as those who left from all across Vietnam since 1975. The political refugendity is likely the most prominent theme in the Vietnamese diasporic experiences, whose impetus is the unending culmination of the Vietnam War in 1975. In the excerpt of Du Tử Lê's poem, the refugee feels reduced to "a yellow rat" that is useless - a perspective that differs markedly from Mai Thảo's orientation as a refugee, who looks at his migration as a journey into light and freedom. The refugee in both Mai Thảo and in Du Tử Lê shares the same purpose: to leave one's hometown or home country in search of freedom. The difference, however, is that with the latter, the Vietnamese refugee is now thrown into the global context, into a space outside of Vietnam. Mai Thảo speaks through a third person, his fictional character Phượng. Du Tử Lê speaks directly from his experiences through the pronoun "I," alluding to the possibility that refug-endity becomes much more personal for the Vietnamese in 1975. Moreover, though Phượng feels a sense of international solidarity with those searching for freedom in other parts of 
Trangdai Glassey-Tranguyen- Articulating Refug-endity in VietnAmerica and the Diasporas

the world, he is still in his homeland. This sense of solidarity only makes him stronger, and more confident in his choice and the future ahead. That was the spirit of the Vietnamese leaving the North for the South. While Phượng agonizes over his separation from Hà Nội, he leaves with a heart full of hope, headed toward the horizon of light, the land of freedom. Yet the Vietnamese escaping Vietnam in 1975, while also leaving in search of freedom, carry a sense of boundless loss as they leave their country for good. This sense of loss from migration is coupled with the loss of South Vietnam as a homeland on April 30, 1975. This time, the Vietnamese leave their birth country to enter the world, and though they are also searching for "a horizon with air and light," to use Mai Thảo's phrase, the pain of bidding farewell to their motherland has precluded any space of light.

\section{ETHNIC AUTONOMY}

Since their arrival in the U.S. in May 1975, Vietnamese refugees and immigrants ${ }^{\mathrm{x}}$ have embraced the freedom of expressions and the available resources to publish their writings, first in print, broadcasting, and more recently online. These publications range from (news) stories relevant to the ethnic community to topics pertaining to the Vietnamese American experiences, including works by established as well as aspiring writers. In this entry, I choose to loosely focus on Vietnamese Orange County for the following reasons. First, albeit my participation in Vietnamese-language publications in Canada and European countries over the last twenty-one years, I am much more familiar with the Vietnamese American community in California's Orange County than elsewhere as this has been my home site for over two decades. Second, this choice is apt because of Orange County's leading role in many things Vietnamese diasporic, and its being home to the largest concentration of Vietnamese outside Vietnam. Third, it is impossible to discuss fully the global Vietnamese literary scenes in this entry-hence the focus on a particular site - though I will gesture towards an understanding of refug-endity in the transnational context of the twentieth century in the next section on global visibility. Nonetheless, my discussion of Vietnamese Orange County and VietnAmerica is informed and shaped by my comparative analysis of the Vietnamese diasporic connections that stem from my multi-sited research in North America, Europe, Australia, and Asia.

Owing to the situations that lead to the emergence of the Vietnamese diasporas in 1975 , an important thread that runs deep across refug-endity is nationalism-felt and expressed in different ways - though it might come across more dominantly in the Vietnamese diasporas' transnational politics. At the onset of their arrival, ethnic Vietnamese embrace the newfound freedom in publishing as part of the freedom of speech in America. Those who have had firsthand experiences living under Communism post-1975 are particularly keen about celebrating the freedom of expression found in their host country. The mass concentration of Vietnamese refugees in Orange County, CA, USA, offers many opportunities for writers and readers alike, and helps form a literary environment that is unmatched anywhere else in the diasporas. The various genres of the letters-from poetry, novels, literary magazines, to print and broadcast media - thrive together in mutual support. As is the case elsewhere, most of the first editors-inchief of Vietnamese-language media in Little Saigon, Orange County, are well-known authors in pre-1975 South Vietnam, with the Vietnamese language playing a key role in this development. Through their ethnic language, Vietnamese refugees gather, continue their literary works from South Vietnam, create communities, and forge new possibilities. This diasporic Vietnamese 
Trangdai Glassey-Tranguyen- Articulating Refug-endity in VietnAmerica and the Diasporas

literary corpus has been made more accessible globally through the internet in the last fifteen years.

While acknowledging the efforts, presence, and contribution of all writers, I argue that the established and committed writers - several of whom have passed away-are those that produce works critical to the making of Vietnamese refug-endity because of their ability to convey lived actualities and perspectives in the most powerful way. These established writers continue the momentum they had built in pre-1975 Vietnam, relocating friends from other countries such as Canada and different European nations to join their endeavors to create a new literary and media scene in the U.S. They create an autonomous space that has evolved into a new phase of integrating into the mainstream-despite maintaining their primary use of the Vietnamese language - through e-publications, blogs, amazon distributions, books translated into English, etc. These writers create a space in which they reflect their own experiences and perspectives, as well as those of their ethnic fellows and their cultural communities' outlook on their lives in VietnAmerica and the diasporas. Far from being passive, these writers put the craft to full use: self-publishing, founding writers associations, establishing publishers and writing programs, creating media outlets and literary magazines, continuing the works that they had created in pre-1975 South Vietnam, and enabling a conduit between the "refugee" literature of Vietnamese-Americans with the hybrid and/or American-born literature of 1.5 and subsequent generations.

\section{Refug-endity: Transnational Autonomy and Cultural Sense of Home}

In the midst of this new literary environment, Vietnamese-language media plays a crucial role in informing, influencing, and inciting the Vietnamese contingent about pertinent issues, as well as new literary works pertaining to their refug-endity and beyond. The thriving Vietnameselanguage media in Orange County attest to the fact that they are indeed the "fourth government," where the community gathers, dialogs, contests, and exchanges information. Owing to its traditional roles and feasibility in the late 1970s, the Vietnamese American print media has a particular and important role in that it promotes, sustains, and spreads the use of the written Vietnamese language since the start across the social spectrum, not just among writers. As a strategy to engage readers in the writing process and to seek new talents, several Vietnameselanguage daily news agencies have hosted writing contests in Vietnamese and published anthologies of these entries, such as Viết Về Nước Mỹ - Writing on America by Việt Báo Daily, Câu Chuyện Người Vọ Tù Cải Tạo (Stories of the Wives of Gulag Detainees, my translation) by Viễn Đông Daily, and scores of thematic contests by Người Việt Daily. Likewise, the Vietnamese-language broadcast media provides much-appreciated albeit-limited entertainment, visual performances, and coverage of community affairs since the beginning; and in 2010s have undergone unprecedented expansions and diversifications with new Orange County-based stations broadcasting through US-wide and Australian networks. Programs with immediate relevance to the community continue to thrive, with shows catering to diasporic-born and -raised generations on the rise in recent years.

This ethnic autonomy is extended to those living in Vietnam and do not have the freedom to publish their works or voice their opinions, as well as those living in other parts of the Vietnamese diasporas where publishing conditions and audiences are not as viable as those in Orange County. This extension of autonomy to writers living in Vietnam makes the country 
Trangdai Glassey-Tranguyen- Articulating Refug-endity in VietnAmerica and the Diasporas

diasporic in a very real sense ${ }^{\mathrm{xi}}$, and challenges any assumed boundaries between Vietnam and the Vietnamese diasporic worlds. This extension remains strong and relevant until today, forty years after the genesis of the Vietnamese diasporas, and complicates the articulations of "home," which is a prominent leitmotif in Vietnamese refug-endity. Home was and is Vietnam, and has been in the diasporas as well. The sense of home and the longing for home alludes to "home" as a reality that goes beyond the place on the map where one lives. The role of the cultural community in VietnAmerica has a deep impact on the experience of the immigrants and refugees, providing a space both tangible and imagined for the (re)construction of a past home and a new transnational home. The place that was once home to the group remains home in their hearts. The strip of land along the Pacific Ocean still holds its pull with powerful fascination and genuine attachment. It is worth noting that those born and raised in Vietnam are bound to feel this keen connection with their birthplace; this is the repercussion of enculturation as a corollary to migration and acculturation.

The social construct of ethnicity takes into account the sublime vigor of cultural activism. Literary expression is a familiar means through which this experience intensifies. The first home is not distant when one finds ways to preserve it in the second home, even if only through reminiscences, such as those offered by the prominent author and editor Phạm Phú Minh (Glassey-Tranguyen \& Phạm, 1999) about his first visit to Hà Nội (my translation),

... Besides the many unique scenes and sites that distinguish Hà Nội as a reality, it only exists and manifests itself in imaginative fascination. I was tuned into the lasting history of the place itself. Upon my return to Saigon, I fell right into writing about my one-month sojourn. The essay was secretly sent abroad and published in Người Việt Xuân, the 1980 spring volume, entitled "Hà Nội in My Eye," under my pen name Phạm Xuân Đài.

Like "home," culture - dormant or active - is something that is carried in the blood. Some first-generation Vietnamese Americans believe that subsequent generations are completely lacking language skills and cultural intuition, but this belief may be biased. As much as their refugee parents want them to retain the cultural identity, 1.5 and successive generations struggle with the challenges to keep their limited ethnic cultural knowledge while driven to identify with the mainstream society. Value systems, they realize, can be shared across ethnic lines but need to be tied to one's cultural background. Knowing one's root can be beneficial to one's psychosocial development. Recording artist and musician Simon Levan (Glassey-Tranguyen \& Levan, 2000) discusses his desire to transmit his culture's values to others. Naming his recording studio in Orange County's Little Saigon "Song Lang," a Vietnamese ethno-music metronome and percussion, Levan reflects, “...I realized that I wanted to use music as a part of a world where I can help the youth at risk and show them what is love, and the value of a family. That goes to any culture."

\section{Refug-endity: Divergent Themes in A Democratic Open Forum}

This autonomy of creative expressions and multi-genre publications makes Orange County an open and complex laboratory in which established and emerging voices co-exist, divergent orientations intersect, and contesting tendencies come into contact. I would like to stress that this autonomy is crucial and important to the development of Vietnamese Orange County and 
Trangdai Glassey-Tranguyen- Articulating Refug-endity in VietnAmerica and the Diasporas

VietnAmerica, for these refugee ethno-scapes are highly contesting owing to the intrinsic diverse perspectives and orientations. Some individuals would have more advantages to exercise their autonomy than others, either owing to their social connections and backgrounds prior to 1975 in South Vietnam, and/or their successful acculturation in the U.S. As such, the exercise of ethnic autonomy is evidently uneven and variegated for people from all walks of life. Some forms of work also lend themselves much more readily to this exercise than others in terms of public presence, such as the media and publishing world, yet each individual has relatively equal right and opportunity to express themselves. This perspective comes from the ground-breaking study Vietnamese American Project ${ }^{x i i}$ VAP, which I founded in the 1990 s at California State University, Fullerton. The VAP oral history narratives serve as an open democratic forum that brings together voices of Vietnamese Orange Countians from all walks of life. The juxtaposition and confluence of these at-times opposing first-person voices help enhance the equality of autonomy across the community.

In the following section, some choice examples help show the broad topics found in VietnAmerica's refug-endity through the exercises of ethnic autonomy. Common genres include memoirs, novels, documentation, poetry, and hybrid works that combine any two or more of the aforementioned. As some refugees feel the urge to write, paint, or compose music during their escapes from Vietnam and/or during their stay in the refugee camps, the richness of these works convey the immediacy of their situations and instantaneously win the hearts of their ethnic fellows. These works would remain "classics" to the Vietnamese refug-endity because they conjure up a particular time and place cognizant and deep-seated in the refugees' psyche. During the early years following 1975, songs such as "Vĩnh Biệt Sài Gòn" ["Fare Thee Well, Sài Gòn"] (my translation) by MC and activist Nam Lộc and "Biển Nhớ" ["The Pining Ocean"] (my translation) by the late Trịnh Công Sơn ${ }^{x i i i}$ appeal to the newly arrived refugees. "Vĩnh Biệt Sài Gòn" recalls the abrupt unwanted departure from the beloved Capitol of South Vietnam. "Biển Nhớ" was ubiquitously sung when someone left the refugee camp back in the day. While these songs are still appreciated today, the distance of time and the establishment of a new home (and even an informal country such as VietnAmerica) in the U.S. and the diasporas render the songs more nostalgic and inspirational than the expressed urgency as they once were.

\section{Refug-endity: Music as Collective Ethnic-Consciousness}

Music has an unparalleled place in VietnAmerica's daily life. This is an extension of the role that music plays in the cultural life of Vietnam, where people from all walks of life perform and enjoy the art of music, from farmers singing while working in the rice paddies to musicians performing in concerts for the royal family. This helps explain why the music industry has continuously blossomed in the Vietnamese diasporas during the last four decades. Songs that speak to the experiences of ethnic Vietnamese while at home, at sea, and abroad have a special place in people's hearts, and remain relevant over the years with strong emotional and cultural captivation. For example, songs by the late Trầm Tử Thiêng (1937-2000) were particularly embraced for this reason. The Vietnamese life runs through his music, his rendition of the loneliness of a Vietnamese heart away from home hits home for any diasporic Vietnamese. In his songs, one comes into complete exile - psychologically, emotionally, homelessly, ecologically, linguistically, culturally. Known for his timely compositions about Vietnamese issues such as the boat people and the South Vietnam commemoration of a lost country, Trầm Tử Thiêng is 
Trangdai Glassey-Tranguyen- Articulating Refug-endity in VietnAmerica and the Diasporas

celebrated and appreciated for his eloquent articulation of the Vietnamese psyche and hope. How well does he speak with so many voices and of many experiences! While the Vietnamese people consider him a musician, I see him as a true activist in many ways. When he calls forth the Vietnamese fellowship and assistance for the stranded boat people in "Bên Em Đang Có Ta" ["Here By Your Side"] (my translation), or in his "Một Ngày Việt Nam" ["A New Day for Vietnam"] (my translation), this well-loved composer helps define the next step for his fellow people. He opens a new door in a time of bleak disorientation, pointing a way home.

Another of his renowned songs "Một Đời Áo Mẹ Áo Em" ["The Life of Her Blouse"] (my translation) recounts the lineage of the Vietnamese women, a history of pain and wars. Yet in its pensive and pining mode, the melody conjures a life that rises from amidst all deaths - the coming of age of a young maiden, the ardent love of a newlywed wife, the joy of a first-time mother-all expressed through the states of her blouse that correspond to the stages of her life. First, there is life. There is joy. There is anticipation. Then, there is death. There is pain. There is reality. She will need to drown herself in the Hát River to keep herself untouched by the invaders, like the historic heroines Bà Trưng Bà Triệu. She will need to put the strip of white cloth around her forehead to signify the death of her father, her husband, her brother, and her child. But she will continue to live, even in the last blue ray of the sunset, when her heart has stopped beating for it had joined the silent heart of her beloved in the newly-paved earth grave. But more than anything, she will live - should the color of her blouse fade, so be it.

\section{Wars, Hope, and Remembrance in VietnAmerica}

Recollections of the past and the lost country of South Vietnam inundate refug-endity writings. Hoàng Xuân Sơn's Cũng Cần Có Nhau [In Need of Each Other] (my translation) (2013) offers the slow-motion clips with commentaries about a tumultuous historical period (GlasseyTranguyen, 2013a). His book reads like a European-style documentary, in which the cinematographer walks backward, faces the people on the screen, and records. There are times the text is burning with youthful idealism, materializing dreams and hopes. There are times the author jumps up and down with the rhythm of zealous youth, causing the film to move faster than usual. And there are times when he slows down, zooming in on destructions and desperation. But there are always two Hoàng Xuân Sơn: one in the film, and one as bystander. Cũng Cần Có Nhau is a love letter that Hoàng Xuân Sơn writes for all the friends he has lived with through the recent chapters of Vietnam. Though he calls himself a bystander in this book, Hoàng is truly a hinge that connects the door of today with the house of yore. One poignant moment in the book is the author's encounter with his close friend, the late composer Trịnh Công Sơn, who invites him to sing "Nối Vòng Tay Lớn" [Connecting One Big Circle] (my translation) on the new regime's radio waves after April 30, 1975. The author declines, and like other friends of Trịnh's at that time, is perplexed about which side the composer is on. But in the end, they remain friends. This is a personal choice, as many later view Trịnh as a traitor and an embedded Communist in the Republic of South Vietnam. The ideological division between freedom and Communist subjugation remain strong today in the Vietnamese diasporas.

War memories (Glassey-Tranguyen, 2008) continue to haunt refug-endity-and not just the refugee generation themselves, but the subsequent generations as well, as discussed in the next section. In April 2004, I conceptualized and crafted a multi-disciplinary program entitled "Faceless Wounds, Nameless Peace" that combined CSU Fullerton's Asian Heritage Month 
Trangdai Glassey-Tranguyen- Articulating Refug-endity in VietnAmerica and the Diasporas

(which was celebrated in April instead of May, when students have finals) and Orange County's Little Saigon's Black April commemoration. The event was held at Người Việt Daily News, Orange County, California, and featured multi-generation writers and artists from various genres, including film, poetry, visual art, documentary photography, and music. Howard Vũ premieres his short film "Running in Tall Grasses - Chạy Trong Cỏ Cao" at this event. Brian Đoàn exhibits for the first time his collection of "The Forgotten Ones"- the images depicting the life and plight of stateless Vietnamese in the Philippines, which were published as a book the following year. The late $\mathrm{Du} \mathrm{Ca}$ composer and journalist Nguyễn Đức Quang ${ }^{\text {xiv }}$ (Glassey-Tranguyen, 2012a) leads the participants in youth songs popular since the 1960s that were also related to the theme. I write the English lyrics for one of the songs, "Hy Vọng Đã Vươn Lên" [Hope Is Risen] for everyone to sing along at the end. In response to my invitation and the theme "Faceless Wounds, Nameless Peace," poet Trần Mộng Tú ${ }^{x v}$ pens War and Seasons of Yellow Flowers (my translation) (Glassey-Tranguyen, 2004a) and recites it in Vietnamese at the event, accompanied by my English reading. She also recites another poem in Vietnamese entitled Quà Tặng Chiến Tranh [The Gift of War] (my translation). The thematic poem reads:

my beloved was killed in war my beloved had died for peace bomb shells had scattered bones and flesh they bloomed amidst poised sunflowers

today, i wake him up from death this day i pat on dawn's shoulders joy finds itself on old time's stiff a smile has bloomed in sunflowers

somehow i walk the unknown yards beckon the past come home to me today dry tears salty no more the tears burst out in sunflowers i come to be at strange doorsteps the sun cuddles my wooden hands the hands that reach for faceless wounds the wounds that set sunflowers free

i am, estranged, on life's front porch, and rise, a nameless peace $i$ call $i$ let a dove into air's wings a dove that summons sunflowers

The poem captures the retrospective psyche of a woman having lived through wars and trying to come to terms with the faceless wounds and a nameless peace - the true aftermath of the Vietnam War, which was officially ended but its consequences are still very much alive decades later. The poem speaks both of a desire for peace and the reality of post-war trauma- 
Trangdai Glassey-Tranguyen- Articulating Refug-endity in VietnAmerica and the Diasporas

the pain that will not heal, the wounds that are invisible. One way to survive wars is to keep hoping - and it might have been for this reason that Nguyễn Đức Quang composes the following song in 1964 in the midst of wartime chaos. This song is a sing-along to conclude the program "Faceless Wounds, Nameless Peace," after the late composer's performance of "Chuyện Quê Ta" and "Việt Nam Quê Hương Ngạo Nghễ." My English rendition of the lyrics (GlasseyTranguyen, 2004a) is as follows:

In the midst of night, we have seen tomorrow

From the depth of war, we've come home to find peace

No longer exiled, we reclaim our nation

The arrow of time has circled to enflame the darkness

On the barren fields, we have toiled a lifetime

In the sad terrace, we've flooded white rivers

When the train is yet to arrive at its stop

A new day is born for us all, like a boat that streams on

Hope has found its place on your face, in my hands

Faith declares its vow to the mindful at heart

In our steps forward, we aspire evermore

Hope is shining bright in your heart, in my heart, in all hearts

Rising from abyss that we once had tasted

You have wakened us with sunshine, with warm breaths

Hope is blossoming for the love of the world

Hope is here for today, tomorrow, and ever

\section{Trauma and Injustices in Post-war Vietnam}

Yet when the Vietnam War ends, hope does not prevail. The degradation of human dignity, the violation of human rights, and the persecution of human lives are prevalent in postwar Vietnam $^{\mathrm{xvi}}$. I argue that the Vietnamese language is prostituted after April 30, 1975, when the new regime imposes the language of the "liberation" army from the North in the South. The "guerilla" version of the mother tongue is used against its own people, as a form of ostracism, persecution, and oppression. Therefore, the boundless efforts to preserve the Vietnamese language and its integrity since 1975 in the diasporas can be seen as both a resistance against the adulteration of the Vietnamese language by the Northern force, and as an insistence on preserving the ethnic roots of the respective communities around the world. I have argued elsewhere that language contains culture, and the preservation of language comes hand in hand with that of culture. This is another transnational aspect of Vietnamese refug-endity, in which the diasporic communities exercise their autonomy in relation to events taking place in their home country.

In his 1992 classic novel Bụi và Rác [Dust and Trash] (my translation), the late author and former lecturer at UC Berkeley Nguyễn Xuân Hoàng (1940-2014), who is greatly influenced by French intellect such as Jean-Paul Sartre, records the absurdity of the Vietnamese language 
Trangdai Glassey-Tranguyen- Articulating Refug-endity in VietnAmerica and the Diasporas

brought to the South by the Northern army and coerced upon the South in 1975 . The murder ${ }^{\text {xvii }}$ of the Vietnamese language comes hand-in-hand with the socio-political oppression and persecution of the South Vietnamese people, which leads to the continuous waves of departures from the country at all cost. This murderous injustice further reduces everyone and everything to just dust and trash, hence the title. Nguyễn's collection of short stories, Căn Nhà Ngói Đỏ [The Red-Roof House] (my translation), brings together the fragments of the Vietnam War, of Vietnam's colonial history, of war-related personal loss and desperation, and of the pertinent questions about human existence. He finds that love is a luxury during wartime, and even more so under a dictatorship long after the bombs have ceased to explode.

War and postwar memoirs of various styles are also prominent in VietnAmerica's refugendity, with battlefield and re-education camp experiences as two diametric chapters in the lives of hundreds of thousand Southern Vietnamese young men of that time. Phan Nhật Nam's 2013 Phận Người, Vận Nước [A Person's Lot, A Country's Life] (my translation) is a hymn to his fellow servicemen, the Vietnamese civilians, and a ravaging historical period of his motherland (Glassey-Tranguyen, 2013b). Calling himself "a soldier-writer," Phan prepares a literary commemoration for those who had lost their lives in war. Each page is an anniversary ${ }^{\text {xviii }}$. Each chapter title is an incense burner. Each story is a wooden tablet with the name of a region in Vietnam, of a fallen fellow serviceman, of a battle - the wooden tablets that wear the mourning headbands. Phan Nhật Nam searches for the non-material remains of his fellow servicemen to give them a proper burial, out of his sense of duty and brotherhood. Phan's focus on the experiences of people across the social spectrum chimes with my use of personal oral history narratives to compose a collective history in the VAP (Tranguyen, 2004a), which acknowledges each individual's role and space in Vietnam's recent history. Phan's works are like the collective anniversaries that commemorate the lives of Vietnamese soldiers and civilians lost in war. His words are the requiem for a motherland that has died without a burial.

But the battles after the 1975 nominal peace and ostensible unification are even more devastating - the battles for freedom when one is stripped of all the means to defend oneself. The Vietnamese Communist gulags, which the new regime euphemistically called "re-education camps" (trại cải tạo), is a topic central to the Vietnamese refug-endity. These strenuous labor camps - or what I call "the Vietnamese gulags and killing fields"-aim at physically and mentally destroying its detainees, who are the South Vietnamese intelligentsia, former ARVN servicemen and women, artists, writers, professionals, religious leaders, etc. There are hundreds of books and articles in Vietnamese (and in English to a lesser extent) about this topic (see, for instance, Đỗ Văn Phúc, 2008), by both skilled writers and others, the majority of whom are male due to the gender ratio in the ARVN and professionals deemed dangerous by the new regime. A small number of books, such as Nguyễn Thanh Nga's 2007 Đoá Hồng Gai [The Thorn Rose] (my translation), offer a female perspective of enduring and surviving the Vietnamese gulags. The late journalist Vũ Ánh's Thung Lũng Tử Thần [The Valley of Death] (my translation) is first published as a weekly column in Người Việt Daily News, and posthumously published as a book in July 2014. In the keynote address (Glassey-Tranguyen, 2014b) at the book release, I observed that Vũ Ánh, like other authors writing about the Vietnamese re-education camps, does not claim his book to be a historical or literary work. He says he simply writes down the moments that have survived in his memories twenty five years after his release from the gulag, and because these moments persist over time, they are likely to be realistic and reliable ${ }^{\mathrm{xix}}$. There are fellow detainees from the same camps - including his fellow inmate, the highly-respected writer Phạm 
Trangdai Glassey-Tranguyen- Articulating Refug-endity in VietnAmerica and the Diasporas

Xuân Đài-who attend the book release and attest to the validity of Vũ Ánh's weekly columns and the culminated book.

In the preface, the author states that he does not aim to write a work of literary or historical nature, but to share his past experiences with his own descendants and those of his fellow detainees. I argue that because of this very reason that the book can attain the highest level of accuracy in conveying the human experiences and perspectives between the walls of the gulag. From the perspective of an oral historian, I can assert that The Valley of Death is a valuable history work which stays true to the human experiences and illuminates an important historical period of Vietnam. Through his twenty-five years of reflections and retrospect, Vũ Ánh lets all the trauma and injustice of the gulag filter through his psyche, so that he has reincarnated as a writer who writes from the vantage point of a skilled journalist living in a free country. His peaceful heart allows the readers to encounter The Valley of Death with clarity and serenity.

In the terse paragraphs at the start of Đại Học Máu [The Blood University] (my translation), another work on the Vietnamese gulags, the author Hà Thúc Sinh writes ${ }^{\mathrm{xx}}$ (my translation),

This book is not a novel or literary work, nor is it a political or prisoner memoir. This book, in fact, can only be considered as a pile of ore, excavated and kept in its original true form. Or in other words, the seventy two chapters in this book can be viewed as seventy two photos, taken continuously by a fortuitous and parsimonious photographer, who captured seventy two sad but meaningful scenes in the (Vietnamese) Communist gulag. Or in yet other words, this book is a report by a former ARVN soldier, who was abandoned, imprisoned by the Communist, had successfully escaped, and is writing what he witnessed for those who still love and are concerned about Vietnam and the Vietnamese people left behind...

While Hà and authors of similar works claim to be genre-free and their works having no literary merit, these works possess great literary riches, with exquisite use of figurative speeches and a dexterous exploit of the art of humor for such bleak topics as the Vietnamese gulags.

\section{The Boat People Phenomenon: Its Extensions and Missing Part}

Another traumatic motif salient in Vietnamese refug-endity is the boat people experience. This topic has spawned numerous writings, with archives being established ${ }^{\mathrm{xxi}}$, memorials erected $^{\mathrm{xxii}}$, and pilgrimages made to the former refugee camps where the UNHCR processes boat escapees for admission to a third country. Since I will elaborate on this in the next section, I would like to emphasize here that despite of this plethora of archival materials and activities, there is a missing part: the experiences of boat people from Northern Vietnam. This lesser-known group came later and many of them resettled in various countries, especially Sweden, where the majority of them are ethnic Chinese Vietnamese (Glassey-Tranguyen, 2015). When it comes to the Vietnamese diasporas, the focus has mainly been on Southern Vietnamese leaving the country after 1975. However, there is a large number of Northern Vietnamese leaving the country in a multitude of ways: guest workers through labor migration to socialist countries, entrepreneurs, exchange students, diplomats, and boat escapes. For the boat people from Northern Vietnam, their 
Trangdai Glassey-Tranguyen- Articulating Refug-endity in VietnAmerica and the Diasporas

prospects are slim as their escapes happen during the very last waves. Đương Phía Bắc (2012) [The Northern Route] (my translation) by Lê Đại Lãng, a writer living in Vietnam, is a rare book that brings together the accounts of many Northern Vietnamese boat people who did or did not make it to a third country. They face horrendous sea dangers, treacherous land dilemma, and rejections at the refugee camps for coming after the UNHCR has applied strict and arbitrary screening procedures for admittance to a third country. I argue (Glassey-Tranguyen, 2012b) that The Northern Route is a silenced history of the boat people coming from the North, whose experiences and stories remain shrouded and unknown in the Vietnamese diasporic historiography.

\section{Preserving and Interpreting ${ }^{x \mathrm{xii}}$ Vietnamese Cultural Heritage}

Besides articulations of contemporary experiences, an important component of the Vietnamese diasporic literature and arts has been the inherited treasures and contemporary interpretations of Vietnamese culture. There is a wide range of cultural heirlooms that diasporic Vietnamese seek to preserve: language, music, arts, philosophy, customs, etc. One example is to reach far back in the past to bring out precious gems unfamiliar to the young generations today. Nguyên Giác Phan Tấn Hải, the Editor in Chief of Việt Báo Daily News, gathers, annotates, and translates into English a 2010 three-volume collection of poetry by ancient Vietnamese Zen masters (GlasseyTranguyen, 2011b). This collection helps bridge the gap between the new readership and the erudite ancient texts, and contributes to the appreciation of Zen practices increasingly popular in the West of late. The collection is a treasure trove containing the paragon of Vietnamese poetry, Zen philosophy, and Vietnamese cultural thoughts. Poetry lovers will appreciate the eloquent expressions, the choice diction, and the unexpected rhythm. The Zen practitioners will find the koans, the thoughts, and the portals that lead to the boundless Zen world. Those upholding the Vietnamese culture will engage with cognizant ethnic images, emotions, and thoughts.

There is also a strong and enduring movement to preserve and develop the "traditional" Vietnamese music ${ }^{\text {xxiv }}$ in the community. These activities later on become a part of the curriculum in public schools and universities. Dr. Nguyễn Thuyết Phong, graduate of Sorbonne University, founder of IVM Institute of Vietnamese Music ${ }^{\mathrm{xxv}}$, and U.S. National Heritage Fellow, travels across the States to record the instrumental and vocal performances of Vietnamese music in people's homes. In his 1995 book Searching for a Niche, Nguyễn relays how he comes to be one of the prominent guardians of Vietnamese music abroad,

...In Japan and Europe I had been engaged in performances of traditional Vietnamese music since 1973. I traveled with theatrical troupes from Paris to Amsterdam, from Lyons to Bern and Stuttgart and sensed all of its vigor. But it was in the United States that I began dealing with Vietnamese music as a real topic of interest. The National Endowment for the Arts and the Social Science Research Council commissioned me with the task of searching for, assessing, and evaluating music in the Vietnamese immigrant communities across the United States. This provide me with artists in several states and see their music in real life and real life in music.... My adventure in this domain revealed, however, that music makers in the Vietnamese communities had one shared view: to continue regardless of whatever happened to them, feeling the need to express themselves through their music (pp. 5-6). 
Trangdai Glassey-Tranguyen- Articulating Refug-endity in VietnAmerica and the Diasporas

When it comes to cultural presence, the voices and practices of ethnic minorities from Vietnam still deserve much more attention than they have now, both in Vietnam and in the diasporas. It is important to include and acknowledge these voices as part of the Vietnamese cultural heritage both inside and outside of Vietnam, especially for groups that have suffered from decimation and marginalization. For this reason, I will devote the rest of this section on a Chăm artist and her works. In VAALA Spring 2012 Art Exhibit (Glassey-Tranguyen, 2012c) "Đời sống tuần hoàn-Cycles of Life," the celebrated artist and writer Julie Thị Underhill ${ }^{\mathrm{xxvi}}$ includes two photos of her grandmother: The Reburial, and Holding. "Holding" is taken in Phước Lập, Việt Nam, with her cousin holding her Chăm grandmother on her deathbed. "The Reburial" is taken during her grandmother's reburial, when a Chăm Balamon holy man offers final rites as family members look on. As a prominent voice for Chăm issues worldwide, Underhill has been fighting for her ethnic group and women issues, among others. Of the photos, she explains,

I have a black-and-white photography diptych of my maternal Cham grandmother in this exhibit, who lived in a small village outside of Phan Rang, Viet Nam. The theme Cycles of Life suits this work well, because the first photo shows my grandmother on her deathbed and the second photo shows her actual gravesite, the day of her second burial. A very small percentage of Cham Balamon, or Hindu Cham, still practice second burials. Yet the Vietnamese American community generally knows very little about our ceremonies and other aspects of Cham culture, so I appreciate the opportunity to exhibit this family portraiture.

Interestingly, during my Fulbright year in 2004-05, I had had conversations about second burial practices with Vietnamese from Hải Phòng living in Sweden and from Hà Nội living in Berlin. As Underhill points out, this practice is generally unknown in VietnAmerica. (I suppose this is due to the demographics of VietnAmerica, the majority of whom came from the South after 1975, many having come from the North in 1954.) Therefore, it is a conscious determination on the artist's part to preserve and insist on the presence of her minority community. Underhill elaborates:

Following my first visit to Viet Nam, my grandmother died, and for two days the holy man could not be found to administer rites. When Thi Oui began to decompose, our family could not afford to pack her in ice. In the absence of the holy man, she was buried without proper sacrament. Six years later, Thi Oui remains in an unmarked grave, awaiting a second burial in the Hindu cemetery in Phước Lập, Việt Nam. An indigenous practice, reburial recognizes the coexistence of the dead and the living, and assumes the interrelationship of the body, soul, bereaved and society. During war, throughout Viet Nam, families forced from their lands also exhumed their ancestors for reburial. The ceremony became necessary for my grandmother, due to her dishonorable first burial. During her second burial, we unearthed Thi Oui's body, cleaned her bones, and moved her to the sacred grounds, as family and friends prayed for three days, feasting and leaving offerings for her and other ancestors. Unlike the Muslim Cham of both Viet Nam and Cambodia, who retain very little of their woman-centered ancestry, the Hindu 
Trangdai Glassey-Tranguyen- Articulating Refug-endity in VietnAmerica and the Diasporas

Eastern Cham remains one of the world's rare matrilineal and matrilocal societies, with property inheritance, political succession and residence passed from mother to daughter. In a culture that venerates ancestors, celebrates mother goddesses, and places women at the head of the house, the reburial of a matriarch holds much significance for the family and the community.

\section{GLOBAL VISIBILITY}

The exercises of autonomy in the refugee generation are more obvious to the mainstream when it comes to economic development and political participation, but not so much in the arts or letters. This is due to the language barrier and the cultural gap between VietnAmerica and the mainstream, or Vietnamese communities elsewhere in the diasporas and the host societies. Yet regardless of this lack of awareness from outside, this sense of autonomy is vigorously fomenting new crops from within. I argue that through their autonomy, Vietnamese refugee generations have helped nurtured the subsequent generations' creative agency. That is, the refugee-generation's sense and practice of autonomy make it more conducive for successive generations to find agency for and in their works. In other words, the first generation's embraced autonomy in the host country is the impetus for the latter generations to reach back into their past and deep into their heritage - while both generations negotiate generational gaps, language barrier, and cultural differences. The 1.5 and diasporic-born generations can certainly take charge of their own creative endeavors. Yet the abundant resources and the open-ended discussions and expressions about Vietnamese refug-endity available in the community - and to a lesser extent in the mainstream archives - can only enrich the new generations' works and perspectives.

\section{The Inter-generational Continuum of Refug-endity}

I want to stress that the lived experiences and enculturation in their Vietnamese homes - or in Vietnam, for 1.5ers - are the most crucial assets for diasporic Vietnamese artists and writers who choose to work on topics pertaining to refug-endity. The terrains of memories, historical recollections, and the act of remembrance span across the personal, generational, national, transnational, and historical scapes. These terrains are uneven, fractured, incoherent, and slippery, as I have discussed in the first half of this entry. Yet as the Vietnamese diasporic-generation artists have shown, these terrains can be useful and productive in hashing out the personal and the political, opening up new interpretations and possibilities. Upon these terrains, the continuity of an ethnic refug-endity is fully visible.

A strong familial connection is present in the works of the younger Vietnamese diasporic generations, despite the fact that their parents might not have been writers or artists themselves. Through their works, these young writers and artists bring the home, the self, and the past into the global contexts and display - the past of their own family, of Vietnam, and of their ethnic community. It is impossible to include all relevant writers and artists of this generations in this entry, as is the case of the refugee generation. The artists and writers included in this section are chosen owing to their particular focus on themes that I deem most relevant to refug-endity ${ }^{\text {xxvii }}$. I also have had the privilege of collaborating with and/or interviewing most of them, and therefore have the unpublished data about their refugee experiences and their works. Some of the primary 
Trangdai Glassey-Tranguyen- Articulating Refug-endity in VietnAmerica and the Diasporas

materials cited in this section are not available in English as they have been published in Vietnamese only, or are from my private archive of research projects I have conducted on the Vietnamese diasporas in the last two decades.

I argue for the continuity of refug-endity in the younger generations, with or without an established tradition of writers and artists in their own families. The artists and writers draw from their families' and their own refugee background, re-creating and re-interpreting their experiences in films, poetry, or arts. It is imperative, therefore, to understand first of all their refugee experiences, and how the memories of these experiences resurface, inform and/or are transformed in their works. For some of the artists and writers discussed, gender orientation and negotiation is an important aspect of their life and works, as well as of their relationship to their family. The first generation's attitudes toward homosexuality is diverse and complex, ranging from outright rejection to open acceptance. Rejection might come with the parents' disappointment with their children's sexuality, and their anger that after all that they had been through as a family, that their children would choose to "disgrace" the parents in such a way. Acceptance could be owed to the fact that having been on the verge of life and death so many times, the refugee parents come to embrace the children as they are. This gender negotiation affects both the artists and their works, either according them the moral support to advance their arts, or fueling them with a sense of estrangement within their own family and consequently enriching their arts in powerful ways.

A lucid example of the connection between younger generation's refugee experiences and their art is the works of Director Khoa Đỗ (Glassey-Tranguyen \& Đỗ, 2009), whose films revolve around the Vietnamese boat escapes (Đỗ, 2010) and their life in Australia (Đỗ, 2001; 2006). Unlike many Vietnamese refugee families who leave the past trauma untouched and undiscussed, Đố's family starts to talk about their boat escapes as a way to bond-and I would argue, to heal as well. Born in Saigon in January 1979, Đố's Vietnamese enculturation takes place in his refugee community in Australia's New South Wales, but more importantly, around the kitchen table (Glassey-Tranguyen, 2014a), where his folks would recount the stories about their 1980 boat escape, much of which Đỗ does not remember. I call this process "reconstructing the past through mealtime stories.” Đỗ (Glassey-Tranguyen, 2014c) reflects:

We had a boat that was about nine meters long. There were about forty people on the boat. We traveled for about five days before we got picked up and taken to Malaysia, to Pulau Bidong refugee camp... It's one of those stories that so often talked about when the family meets for dinner. And towards the end of dinner - always - these stories would keep coming out. 'Remember that time we were on the boat, and the engine broke down. And we lost a propeller, and Uncle Sáu had to jump down and change the propeller. Lucky I brought the extra propeller, see! Mum told me not to bring the propeller, but I brought the propeller, otherwise we would still be drifting now.' All these stories came out, you know. 'Remember that time when the pirates attacked us, we thought they were going to throw Khoa overboard, but luckily they didn't.' And all sorts of stories, and I guess it is from these stories that you construct your history... 
Trangdai Glassey-Tranguyen- Articulating Refug-endity in VietnAmerica and the Diasporas

\section{Reconstructing Memories that Are Slipping Away}

It takes great courage to cross the dark sea-both in real-life experiences such as the boat escape, and in the sub-consciousness when you recall the past-in order to heal. Đố offers a different way of looking at the past: by meshing it with the present. In his 2010 feature film Cá Me Mother Fish (Vietnamese with English subtitles), Đố superimposes the boat escape onto the seamstress shop in Australia, showing how the past continues to be present across time and space (Glassey-Tranguyen, 2011c). Still, memories are uncertain, even when they are actively recalled and (re)constructed. Đỗ is not sure what to make of the pictures of the past: "And as a result of these stories, I have images of the boat. To be honest with you, I don't know whether they are real images, or whether they are constructions of the stories that I've heard." But he recognizes the import of these memories, and the need to preserve them for posterity:

I think it's important that these stories are told, it's important that these stories are passed on. Because I think it's so important to keep our history and we record it for the next generation and the next generation. I'll pass these stories to my children. These stories make us who we are. They are a construct of a whole history. I'm privileged, and I guess fortunate, that my parents did share these stories, that my family does share those stories.

It was the healing process that allows humor to shine through in the life of Vietnamese refugees, such as in the 2006 Footy Legend - Đố's first feature which won several accolades. Set in Sydney's western suburbs, the film tells the story of Lực Vũ, a young Vietnamese Australian man obsessed with rugby league football. Lực is out of work. Welfare authorities have threatened to take away his little sister Anne because he is deemed incapable of being a responsible guardian in place of their deceased parents. Lực reunites his old Yagoona High School "footy" team with members facing social problems such as long-term unemployment, drug addictions, the after-effects of teenage parenting. They win a competition that offers a Holden Ute and a modeling job for Lowes Menswear as its prize. Drawing from his refugee experiences growing up in a rough neighborhood in Sydney with friends from all ethnic backgrounds, Đố chooses to focus on commonality as a way to address racial differences and to gesture toward harmony, coexistence, and collective survival. When I commented that while the film has a Vietnamese lead character, the focus was not about race, Đỗ agrees. That is because for Đố,

...sometimes, to focus on race may not necessarily heal, may not necessarily tackle the issue successfully. Because to highlight the issues, to highlight the problems, may serve to reinforce the wrong discussion. Instead of focusing on race as an issue, we thought, 'Let's focus on what they have in common.' Rather than focusing on differences, which is race, we focus on similarities, on what they have in common, on what they have together. What they have in common is their love of sports, of football, of playing together and being together. I think throughout the whole film, we focus on what they have in common, and their childhood, memories, and what they share - in so doing, I think we tackle and address all of those issues of race and classes, but in a much more subconscious way, in a way that doesn't hammer you in the head. The message is that we must care for each other, no matter what the background is. In my everyday life, that was 
Trangdai Glassey-Tranguyen- Articulating Refug-endity in VietnAmerica and the Diasporas

the reality. Growing up with friends of different backgrounds, we don't necessarily sit together and talk about, 'So, what's it like to be Lebanese? Or what's it like to be an aboriginal Australian?' We never talked about that. So I thought, 'Let's avoid those conversations in the film and go for the similarities...'

Like Khoa Đỗ, Howard Vũ grapples with the past to make sense of what he seems no longer able to remember clearly. In his short film "Running in Tall Grasses - Chạy Trong Cỏ Cao," "xxviii which was his MFA thesis at the University of Southern California, Vũ recalls his first estranging visit to the gulag as a child, disidentifying with his detained father, and demanding an answer to why his father would not come home. Vũ's film is an indication of how childhood memories run deep in 1.5 generations' psyche and beyond. The film won the Jeffrey Jones Scholarship for Excellence in Writing and the American Society of Cinematographers Conrad L. Hall Heritage Award. Born in Saigon a few months after the city fell, Vũ had "missed the 70s as most people in the States have known it." Still, he treasured his early years in Saigon and the boat escape with his family to Malaysian refugee camps where he "learned to love coconut candy and rainy beaches." Vũ accumulated an array of experiences prior to his filmmaking days delivering pizzas, coding computer programs, and freelancing as a graphic designer. These experiences add to the realness in his approach in films. While attending the USC School of Cinema-Television, Vũ won the Cinema Circulus Endowed Scholarship, among others. Of "Running in Tall Grasses," Vũ reflects (Tranguyen, 2004b),

It comes from a little story that I wrote a number of years ago, when I first had the inkling that I remember very little clearly from my early years in Vietnam. The boy in the film, named Vinh, catches his first glimpse of a world that is far more dangerous and complicated than the one he has known.... Life for him and his parents will continue, and they will try to do their best under the circumstances. The new regime that took over after the fall of Saigon in 1975 sent hundreds of people deemed politically dangerous to reeducation camps to 'reform' them, ideologically. These people were former officers, artists, journalists, and religious leaders. But what all of this means to the boy is simply that his father has been absent for a long time.

These childhood memories - despite how deeply they run in the person's psyche-are still on slippery ground. Vũ muses,

The film is very subjective in a lot of ways, and what's interesting is that most of the audience will not necessarily know whether certain events depicted in the film are 'real.' I wanted to get at a certain 'did it really happen that way?' feel that people have from early childhood memories. The strange thing is: in the world of post-war Vietnam, all of it could very well have happened.

\section{War Residues in Diasporic Refug-endity}

"Real" or "unreal," these images and memories prove to be so powerful and persistent, and in certain ways they even overpower the worrisome generational gaps and language barriers that plague the inter-generational relationships in Vietnamese American or other ethnic immigrant 
Trangdai Glassey-Tranguyen- Articulating Refug-endity in VietnAmerica and the Diasporas

families. Post-war situations in Vietnam further complicate things. Vũ was born while his father was taken away and incarcerated in the re-education camps. As a child, he was not concerned with the political injustice his father's cohort faced, but was enraged with the injustice of not getting to be with his father (Tranguyen, 2004b):

This is not a war film, but the evidence of that conflict remains like a residue. The politics underneath are undeniable, but they are not the main focus. I do not want polemics, or convenient sloganeering. It is simply this: a boy's point of view, seeing his parents in sharp focus for the first time. They are there, young lovers, sometimes foolish and sometimes brave. The context, the situation of this discovery, comes through a composite of first-person memories heavily filtered through years of inconclusive dreaming. I am attempting to process these images that I have, to get to their emotional core.

Processing the past and its memories takes great contemplation-or "inconclusive dreaming" to use Vũ's phrase - and innovative expressions, which as Vũ puts it, "to record the texture of memory, impressionistic and even unreliable." Artists of Vũ's generation who were born and raised after the Vietnam War ended wrestle with the residues of wars and conflicts that inundate their sub/consciousness ${ }^{\text {xxix }}$. Like their contemporaries of this generation, artists Bình Danh and Danh Võ have attempted and succeeded in making these residues visible and tangible. In Bình Danh's various projects, the insistence of the Vietnam War's memories take center stage. A Vietnamese-born artist whose work investigates his Vietnamese heritage and the collective memory of wars, Danh earned an MFA from Stanford University in 2004. He has emerged as an artist of national importance with work that investigates his Vietnamese heritage and the collective memory of war, both in Vietnam and Cambodia. Danh describes his works as dealing with "mortality, memory, history, landscape, justice, evidence, and spirituality." Danh invents the chlorophyll printing process, in which photographic images appear embedded in leaves through the action of photosynthesis. He recently focuses on the Daguerreotype process. Danh's works have been featured in important exhibitions at museums across the country, as well as the collections of the Corcoran Art Gallery, The Philadelphia Museum of Art, the deYoung Museum, and the George Eastman House, among many others. He received the 2010 Eureka Fellowship from the Fleishhacker Foundation and is represented by Haines Gallery in San Francisco, CA and Lisa Sette Gallery in Scottsdale, AZ. One of his projects, "Immortality, The Remnants of the Vietnam and American War," articulates the continuum of wars through war images on chlorophyll prints. Danh explains ${ }^{\mathrm{xxx}}$,

I have recorded the images of the Vietnam War onto and into tropical plants. One summer, I was motivated to experiment with photosynthesis and its pigments after observing how grass changed color under a water hose that was left on the lawn. Soon after that, I was making chlorophyll prints. In my work, photosynthesis is used to record images onto leaves using only chlorophyll and light: the life source of plants and, consequently the Earth. The leaves are then cast in resin, like biological samples for scientific studies. 
Trangdai Glassey-Tranguyen- Articulating Refug-endity in VietnAmerica and the Diasporas

In yet another Vietnam-related project, "Ikea, Made in Viet Nam," Danh reflects on the translocal connections of objects and memories.

One day while visiting an IKEA store, I took notice of some IKEA products that have an interesting shape and form that for me connect these forms to my history. I was then surprised to find that these items were made in Viet Nam. So I bought several of these items and arranged them in an installation to suggest the persistent memories of the Vietnam War.

Danh's trademark technique of making chlorophyll prints speaks eloquently of the past and its residues, how they migrate across times, generations, and spaces. In Danh's words:

This process deals with the idea of elemental transmigration: the decomposition and composition of matter into other forms. The images of war are part of the leaves, and live inside and outside of them. The leaves express the continuum of war. They contain the residue of the Vietnam War: bombs, blood, sweat, tears, and metals. The dead have been incorporated into the landscape of Vietnam during the cycles of birth, life, and death; through the recycling and transformation of materials, and the creation of new materials. As matter is neither created nor destroyed, but only transformed, the remnants of the Vietnam and American War live on forever in the Vietnamese landscape.

War remnants live on forever, indeed, and it is in the act of remembering that an artist transform the past and evoke the future. Like Bình Danh, Danh Võ revisits the past through personal experiences, and while relegating himself outside of his arts, has brought together his personal and historical fragmented pasts. Born in 1975 in Bà Rịa, Vũng Tàu, and brought to the island of Phú Quốc in the same year, Võ escaped by boat with his family in 1979 and was rescued by a freighter of the Danish Maersk shipping company. They settled in Denmark. Võ pursued a career in the arts, and was at the Royal Danish Academy of Fine Arts in Copenhagen before he attended Städelschule in Frankfurt and has been based in Berlin since 2005. Võ has been exhibited internationally, such as at the Art Institute of Chicago in 2012-2013; Kunsthaus Bregenz, Austria in 2012; National Gallery of Denmark, Copenhagen in 2012 \& 2010; Kunsthalle Basel, Switzerland in 2009; MoMA, New York 2009; Stedelijk Museum, Amsterdam in 2008; Bergen Kunsthall, Norway in 2006; the Shanghai Biennial in 2012; the 2013 Venice Biennale; the Museion in Bolzano, Italy in 2013; and the Guggenheim Museum in New York in 2013, etc. Võ has held residencies at the Villa Aurora in Los Angeles in 2006, and at Kadist Art Foundation in Paris in 2009, among others.

\section{Vietnam as a Transnational Refugee: From the Personal to the Political}

If Howard Vũ draws from his short but memorable first years in Vietnam, Danh Võ draws from the historical archives to grapple with his personal past and Vietnam's national history. In Danh Võ's "Mother Tongue" which ran March 20 through April 27, 2013 in New York, the viewers encounter the historical from a personal perspective. "LOT 40. GULF OF TONKIN RESOLUTION, 2013," for instance, is the nib of a fountain pen - the very symbolic instrument that inscribes the fate of Vietnam time and time over from the French colonial period to the 
Trangdai Glassey-Tranguyen- Articulating Refug-endity in VietnAmerica and the Diasporas

American involvement. Danh Võ puts the nib of the fountain pen-an object that is in itself historical in our digital age - to work through the penmanship of his father, Phung Võ, and as the main object of "LOT 40. GULF OF TONKIN RESOLUTION, 2013." The accompanying text reads (use of upper-cased letters original):

ON 2 AUGUST 1964 THE USS MADDOX, WHILE ON AN ELECTRONIC INTELLIGENCE COLLECTION MISSION, WAS ATTACKED BY THREE NORTH VIETNAMESE TORPEDO BOATS. TWO DAYS LATER, ACCORDING TO MCNAMARA'S REPORT, "NORTH VIETNAMESE BOATS AGAIN ATTACKED OUR DESTROYERS [THE MADDOX AND TURNER JOY] ... ON AUGUST 5, U.S. PLANES RETALIATED IN A LIMITED FASHION AGAINST NAVAL BASES WHERE WERE THE HOME PORTS OF BOATS AND THE OIL STORAGE AREA AT VINH WHICH SUPPORTED THEM ... THE U.S. RETALIATION DID NOT EXTEND BEYOND AUGUST 5." A LATER INVESTIGATION BY THE SENATE FOREIGN RELATIONS COMMITTEE LEARNED THAT THE U.S. NAVAL COMMUNICATION CENTER IN THE PHILIPPINE ISLANDS, IN REVIEWING SHIPS' MESSAGES, QUESTIONED WHETHER A SECOND ATTACK HAD ACTUALLY OCCURRED. THE BALANCE OF THE MEMO RECOUNTS NUMEROUS ACTS OF TERRORISM PERPETRATED BY THE VIET CONG AGAINST SOUTH VIETNAMESE CITIZENS AND U.S. PERSONNEL. AFTER LENGTHY DEBATE, CONGRESS VOTED ON 10 AUGUST 1964 ON A JOINT RESOLUTION WHICH AUTHORIZED THE PRESIDENT "TO TAKE ALL NECESSARY STEPS, INCLUDING THE USE OF ARMED FORCE, TO ASSIST ANY MEMBER OR PROTOCOL STATE OF THE SOUTHEAST ASIA COLLECTIVE DEFENSE TREATY REQUESTING ASSISTANCE IN DEFENSE OF ITS FREEDOM." THE RESOLUTION IS OF HISTORICAL SIGNIFICANCE BECAUSE IT AUTHORIZED THE PRESIDENT, WITHOUT A FORMAL DECLARATION OF WAR BY CONGRESS, FOR THE USE OF CONVENTIONAL MILITARY FORCE IN SOUTHEAST ASIA. WHILE MCNAMARA'S MEMO REPRESENTS THE PRESIDENT'S WILLINGNESS TO NEGOTIATE A PEACE WITH THE NORTH VIETNAMESE, THE ADMINISTRATION RELIED UPON THE RESOLUTION TO BEGIN ITS RAPID ESCALATION OF U.S. MILITARY INVOLVEMENT IN SOUTH VIETNAM AND OPEN WARFARE IN NORTH VIETNAM. * (*THE WHITE HOUSE YEARS OF ROBERT S. MCNAMARA: SOTHEBY'S, 2012.)

The above text illustrates how Vietnam - through the Vietnam War affairs and policiesis transnational in that the country has always been part of events beyond its territory and domestic dealings. Another of Võ's prominent installation that speaks of foreign influence in Vietnam is "Go Mo Ni Ma Da"xxxi. The title is very telling of Vietnam's history of Western involvements. An American journalist was greeted with the phrase "Go Mo Ni Ma Da" —or "Good morning, Madame" — during her travels in Vietnam and incorporated it in her article. "Go Mo Ni Ma Da" encompasses four bodies of works: "We The People" with life-size reproduction of the 1886 Statue of Liberty by Auguste Bartholdi, the three Hotel Majestic chandeliers, a work referencing the Catholic missionary priest Théophane Vénard (1829-1861), 
Trangdai Glassey-Tranguyen- Articulating Refug-endity in VietnAmerica and the Diasporas

and the lots acquired from Sotheby's auction of the Estate of Robert S. McNamara. The mixedlingo title and the historical objects across Vietnam's recent history juxtapose Vietnam and the West, both in their interactions (such as in the chandeliers that connotes the ballroom at the Hotel Majestic where the Paris Peace Accords signed between the United States and Vietnam in 1973, or Théophane Vénard as a reference to the Catholic missionary work during the French colonization of Vietnam in the 17th century) and their independent spaces (We The People as an American and Western ideal, or McNamara's estate). I found it most interesting and convincing that Võ has chosen this phrase as the title for his exhibit: a Western-centric phrase that has been Vietnamized, yet reflecting its French and English origins nonetheless. The gaze is from the West, and the Vietnamization can be seen as a form of resistance or adaptation through the act of creolizing Western words. I argue that the duality of domination/influence and resistance/ Vietnamization is key in Võ's articulation of how Vietnam as a nation negotiated its status in world politics in the past (with present implications, to be sure). In that sense, not only that Vietnamese people have become refugees, but Vietnam as a nation state was and has been a refugee in the political negotiations that took place in the West and in Vietnam. Through Võ's works, one encounters Vietnam as a transnational refugee across historical periods.

From the political and national to the personal, the power of memories and lived experiences proves to be inescapable. Even when the parents urge their children to speak only English out of the pressure and desire to assimilate, their ethnic roots resurge when the younger generations come of age and search for their identity, such as in the case of Hàm Trần (GlasseyTranguyen, 2011d \& 2012c), director of the multi-award winner Journey from the Fall ${ }^{\mathrm{xxxii}}-$ among other acclaimed films. Trần relays how his father - out of gratitude for the country that took his family in at a time of desperation - had encouraged his children to embrace Christianity and the American culture. But Trần's enculturation in Vietnam, the thriving and enticing Little Saigon right next to his family's residence in Santa Ana, and his coming of age in college make it impossible to stay far from his own roots (Glassey-Tranguyen \& Trần, 2011; GlasseyTranguyen, 2012d).

An important and possibly less-known fact about Trần is that he is "nuts about [his] family." Family themes are always central in his works, from his short films ${ }^{\text {xxxiii }}$ to his worldrenown Journal from the Fall. His films are steeped in the Vietnamese family's everyday life, the deep-seated childhood memories, the filial love, the oneness of a family, the family's sacred but tangible thread of support that sustains one through the hardest of times. These simple pieces come together as a magnificent picture that helps the world understand a part of Vietnam's contemporary history. To speak of Hàm is to recall his daily life as a child in Chợ Lớn, waking up to the exquisite fragrance of his Vietnamese step-Grandmother's broken-rice stand, the long moonlit nights he stood next to his mother by the iron gate in the last house at the narrow cul-desac waiting for his father to come home from business dealings, the sounds and tastes of Saigon and of his mixed heritage ${ }^{\text {xxiv }}$. All of these lived experiences gestures toward the ethnographic quality of his films: always down to earth, always "real" (to hark back to Khoa Đỗ and Howard Vũ's ponderance), always familial, always relatable to those who have spent some part of their life in Vietnam. Trần builds upon his experiences and perspectives for his short films, like "Ngày Giố-Anniversary," but for the epic Journey from the Fall, Trần interviews hundreds of Vietnamese refugees and creates a composite collective story as powerful as this much-needed film. It is through the lives of its people that Trần re-imagines the life of Vietnam in the latter half of the twentieth century. 
Trangdai Glassey-Tranguyen- Articulating Refug-endity in VietnAmerica and the Diasporas

\section{Refug-endity as "Home" in VietnAmerica}

To speak of the family is to evoke the sense of "home." Home is never a static or stable concept, but a shifting and complex world where the human experiences manifest. In his works, Việt Hồ Lê (Glassey-Tranguyen, 2013c), an international multi-genre artist (re)examines the concept of home through his life experiences as a refugee and his memories of his disabled father's illness and death. Lê's family escaped by boat and stayed in the refugee camps in Thailand when he was two, but he "had no real memories of the boat escape, of the Thai refugee camps. My first recollection is of getting on a plane from Thailand to the United States." Like all refugees, Lê's family struggled to make end's meet upon their arrival, "When we first arrived in the United States, my family shared a house with another family in Garden Grove. We later moved to our own apartment in Orange County. After school, I would skate with the neighborhood kids, Ngan and Phieu." The family worked hard for their survival—not just financially, but for Lê's schooling. Lê recalls,

We struggled as immigrants; my mother and I did sweatshop work at home sewing garments. After an exhausting day at work my father would come home and help me with my homework. I did not find out until my twenties that I was to be held back a grade due to my poor English. My dad had made a 'secret' agreement with my teacher that he would tutor me.

Lê was a "refugee" in many senses: his ethnicity, his sexuality, and his artistic tendency. As a child, he faced disparaging treatments because of his differences,

Although there was diversity in school and neighborhood growing up, I was still a minority. At first some of my teachers couldn't pronounce my name. My teachers at my elementary school, however, were very supportive. My sixth grade teacher really encouraged my drawings. In middle school, it was the intersection of ethnicity and sexuality that I had trouble grappling with. Some other classmates would taunt me for being a 'pansy' as I walked to school each day.

He remembers being called out just because of the colors he was using:

As an undergraduate I would paint holiday windows for the local post office for extra cash. Often, it was cheery Santas, candles and snowmen. As I was painting one day, an American veteran said to me about the red candles and yellow flames I was painting, 'Those colors are not the color of my country, but the colors of your country (referring to the colors of the Vietnamese flag, red and yellow).'

Despite his disability, Lê's father earned an M.A. degree in the U.S. and worked to sustain the family and was also a published author in Vietnamese. When the father fell ill, Lê's mother shouldered the household responsibilities and cared for him. It was Lê's father's journey through illness and death that brought them closer, 
Trangdai Glassey-Tranguyen- Articulating Refug-endity in VietnAmerica and the Diasporas

When my father became bedridden over two years, I was pursuing my MFA and lived away from home. During the same time, I also had a painful cancer scare, so was also physically ill. My mother had to nurse my father and uphold the household. Then, I would visit my family every weekend to try to help. During that time, I became closer to my father, with whom I previously had a somewhat distant relationship. After he passed away, I try to actively keep his memory alive, to envision his spirit when I take hikes by myself. When my father was very ill, I started to take photographs of my family ${ }^{\mathrm{xxx}}$ (as well as other families grappling with terminal illness and death). I wanted to explore loss and the lack of avenues we have for dealing with death in mainstream society.

\section{Refug-endity: Love and Loss}

Lê studied fine arts in college, and pursued an MFA at UC Irvine afterward. His MFA thesis was highly regarded, which "included quiet, large scale photographs of my family, interiors and of my family's struggle with my father's terminal illness. Recently, an image from that series was chosen Sovereign Art Prize, a high-profile recognition." Though he struggles to make it as an artist, Lê is committed to art, his first love,

I am always humbled and grateful for the opportunity to share my work as well as share the works of other artists I love. My childhood wish of being a part of communities of cultural producers has become realized. Caught up with daily mundane details, sometimes I forget the long journey from Viet Nam and back again. My goal is to continue to build dialogue across communities through art.

Of all losses, the loss of a loved one is probably the most difficult to cope with. His father's departure continues to haunt Lê's psyche and art. In a certain way, his father is still alive -in another form, through his thoughts and emotions as reflected in his art. Lê conjures up his $\mathrm{Ba}$ of today, a $\mathrm{Ba}$ that he has re-encountered after the long mourning days,

The other week, I dreamt of my father. I forget the circumstances of the dream, only that we had a regular chat, the stuff of daily life. I still get emotional when I watch films or read stories about fathers and sons, families. My "Ba" of today reminds me of the many modes of transport of transit and of transition: the barge to Thailand, my first plane to the United States, the countless car rides to work to school to run errands. He reminds me that home is in between long hours and long commutes, within and in between transit, untranslatable." In the summer of 2009, Lê traversed the art scenes in Europe, and "created a series of large life-sized paintings entitled 'vestige' based on archival images of deceased soldiers as well as family photographs before the Viet Nam War. This series painted and drawn on large used bedsheets speaks of ghostly memories and the vestiges of trauma. 
Trangdai Glassey-Tranguyen- Articulating Refug-endity in VietnAmerica and the Diasporas

Known as a multi-genre talented artist with a very diverse personality, gender has always been a flexible aspect of Lê's life, because:

As Judith Butler points out, gender is performative. When I was six, I thought of myself as gay. Now I identify as queer. I believe gender and sexuality is fluid, both artifice and art. My art still deals with issues of gender. My latest 'sexperimental' video trilogy (in progress) deals with a transnation transgender love triangle. And it's trilingual! In art and in life, gender, ethnicity and sexuality are just a fragment of what constitutes us as everevolving individuals in flux.

From his personal journey of as a queer Vietnamese American, Lê comes to grapple with the gaps between historical and pop culture in Asia,

Towards this, I have created a series dealing with fake boy bands, installations and art music videos. The boy bang/gang band project consists of campy images and music videos of faux pan-Asian boy bands and solo performers in various guises and costumes, examining the borders of spectacle, (homoerotic) desire, gender, audience, and affect. The hyped rise of bull markets may presage the rise of pop markets, including J-Pop, VPop, and hallyu (Korean Wave). How are consumer and national desires linked? The wholesome appeal of these performing acts insidiously masks other agendas: it is 'popaganda.' In the shadow of post - Cold War diplomacy, it's 'soft power' for hard times. The sweet candy-colored explosion of pan-Asian youth culture is a thin veneer that obscures sociopolitical inequities. This ersatz pop provides a screen for - and perhaps also an escape from - the bleak realities of modernization and historical traumas. Conceived as limited edition fine art objects, the project blurs the line between 'high art' and mainstream consumer culture. The project examines how popular culture is created and consumed within Asia, its diasporas, and beyond.

\section{Regarding the Mother Tongue}

Traversing the national and the historical to the personal, young Vietnamese diasporic artists show that the Vietnamese language remains an important space for reverence, reference, and/or remembrance. Việt Hồ Lê wished that he had invested more time to learn his mother tongue prior to his pursuing heritage language training in graduate school. Yet embracing the mother's tongue isn't always a comfortable option for writers of Vietnamese heritage. Poet Ocean Vương (Glassey-Tranguyen, 2014f), for instance, reveres the language and reserves it for family fellowship - not poetry. Born in Saigon in 1988 and raised by women in Hartford, Connecticut, Vương earned a B.A. in English Literature from Brooklyn College, and authors two chapbooks: No (Vương, 2013) published by YesYes Books, and Burnings (Vương, 2010) published by Sibling Rivalry Press, which was an American Library Association's Over The Rainbow selection and has been taught widely in universities, both in America and abroad. Vương received a 2013 Pushcart Prize, and fellowships from Kundiman, Poets House, and the Saltonstall Foundation for the Arts, as well as an Academy of American Poets Prize and the Connecticut Poetry Society's Al Savard Award. His poems have appeared in Denver Quarterly, Quarterly West, Passages North, Guernica, The Normal School, Beloit Poetry Journal, Crab 
Trangdai Glassey-Tranguyen- Articulating Refug-endity in VietnAmerica and the Diasporas

Orchard Review, Best of the Net 2012 and the American Poetry Review, which awarded him the 2012 Stanley Kunitz Prize. His work has also been translated into Hindi, Korean, Vietnamese, and Russian.

Though Vương was born thirteen years after the Vietnam War ended, his family's history places him right in the middle of it —with the work his Bà Ngoại [maternal Grandmother] did for survival, the deaths of men in his family, and everything else. Yet he becomes conscious of the Vietnam War and negotiates a personal relationship with it on his own:

...when I kept seeing Vietnamese people, often played by white actors in yellow face, get gunned down by John Wayne on the television. I thought it was odd that so many Vietnamese people were being killed by 'good guys.' I thought I must be a 'bad guy.' So I went to library to try to find out what was so bad about me. This was where I discovered books and words. And through books, I learned that you can use words to make anyone be a bad guy or good guy. It was kind of like magic.

Leaving Vietnam at a young age, Vương doesn't

...remember anything. I came to America when I was 1.5 years old. I did, however, return to Vietnam for the first time in 2009. It was a terrifying experience because what I knew of Vietnam at the time were remnants of my grandmother's stories. In other words, the Vietnam I knew of existed in the past, in a time warp. I never thought that by going home, I would feel like an immigrant all over again—but I did.

Negotiating one's identity is a complicated process, more so when one's family history might include stereotypical traits held by the mainstream. For instance, Asian America rejects the mainstream's stereotypes of Asian (and Vietnamese) women as sex workers, and Asians as peasants. Vương embraces his family's farming background and his Bà Ngoại's past as a sex worker, as he once said, "In fact, I'm proud of her. That's not an easy thing to do. She put on her purple dress and did her thing. And she survived." There is no tension in his stance and the socio-racial justice that Asian America fights for, because Vương doesn't:

...see my supporting my grandmother's sacrifices for her family as a socio-racial stance. Pride in one's family and conscious social stances are independent of one another. In other words, why can't one be critical of the American media's stereotyping Asians while still supporting those who had to embody some aspects of those stereotypes in order to stay alive? I think this is an important distinction - especially for upcoming second and third generation Asian Americans who, because of their removal from traumatic Asian histories of the 40s throughout the 70 s, have the privilege of compartmentalizing trauma as socio-racial tropes.

Of his family's past, Vương is trusted with precious stories that would die with the speakers - unlike literature. As the only one in his family with the ability to write them down, Vương did. As keeper of these stories, he takes the responsibility and privilege without feeling the pressure of the role. As a creative writer, he has the option of re-imagining the past, 
Trangdai Glassey-Tranguyen- Articulating Refug-endity in VietnAmerica and the Diasporas

I don't feel the pressure. My family is entirely illiterate - in both English and Vietnamese. What they gave me in their stories was a gift, an inheritance. But, unlike material wealth and relics, it is a gift that cannot break or be stolen. I am grateful for the opportunity to turn these stories, these lives, into art by adding them to my own narratives and inventions. I'm not a historian. And, in that sense, there is less pressure for accuracy. I fill in the gaps and details by making things up.

\section{Transcending Refug-endity}

Being a poet can mean feeling a certain kind of disconnect to one's own family, if not to oneself and to the world in certain moments. But to be the only poet and scholar in one's family-like in the case of Ocean Vương - can augment that sense of disconnect. Yet Vương's close relationship with his family and his practical care for them transcend any gap,

I guess I am also fortunate in that, unlike more traditional Asian-American parents who want their children to become doctors or lawyers, my family is very proud to have a scholar and poet. I think for them, reading itself is a power they have never understood or experienced, and therefore they see it as something worthy of great reverence and importance - even as surreal. There are times I will be reading People or some other popculture trash at the kitchen table and everyone will slowly dissipate from the room, whispering amongst each other, 'Shhhh. Let's go somewhere else. Ocean's reading.' To them, reading is not unlike magic. And in a way, they're right: in our household, I take care of everything regarding words. Even from New York City, I take care of bills, doctors' appointments, taxes-I even go to my younger brother's parent-teacher conferences. It's the least I can do for the sacrifices they have made for me. And I have tried many times to teach my mother English - but it's difficult in an Asian household for a son or a child to teach anything to an adult. The hierarchical roles play a major part in our relationships and such reversals can be very straining, if not impossible.

Having lived through difficult situations, Vương sees poverty as relative. That is,

I never saw myself as living in poverty - although I realize we were terribly poor. In fact, during the time of our immigration, Vietnam was on the rise again. Families began owning TV sets and radios. When we first got to America, we had only a bare room with some blankets from the Salvation Army. I guess you can call that poverty. But we did get help from welfare and the local church, which had food drives that gave out expired cereal and sacks of old bread every Sunday. I don't know. I think that relative poverty taught me what it means to appreciate what I had: the presence of family and the power of stories, images and songs. Also, when you have so little, suddenly every new thing is a gift - a real, felt blessing. And I like that. Nothing is ever boring. Everything is a bonus.

Vương started writing poetry when his Bà Ngoại passed away. Writing as mourning. Writing as recording her voices, so that she remains with him through his works. Death is also relative, because 
Trangdai Glassey-Tranguyen- Articulating Refug-endity in VietnAmerica and the Diasporas

My grandmother will always be a part of me as I am a composite of her stories as well as my own. She taught me that what I will learn or acquire in my life I will already possess - and that each encounter with the world, including its citizens, is the ignition of dormant experiences. In that sense, my grandmother is already inside me-even before she died she was planting pieces of herself within my imagination. She is with me in every word. If I could do one thing for her - I would keep being a poet.

Poetry might very well be the best way to celebrate and commemorate the person that from the way Vương talks of her-seems to be most influential to him, since she was his caregiver, his Vietnam. If he were able to write in Vietnamese, would he feel a whole different way of being with her and of remembering her? Not necessarily. He proffers,

The Vietnamese language is precious to me because it is the language I use in the kitchen, with my family. It is the language in which I learn of the deaths and births of my kin. In this way, it is free of art and its complexities. When I speak Vietnamese it is speaking in pure water. I am most relaxed. I can say anything and nothing all at once. So I wouldn't want to write in it. I don't want to use that language for poetry. I don't want to taint it. Besides, the music, the intonations in the Vietnamese language are poetic enough.

Unlike some Asian families who find it difficult to accept their gay children, Vương's family is more open to his sexuality because, as he explains, they have lived through grave adversities. Vương recounts,

I told my mother when I was 18. She just said: 'Does this mean you going to start wearing dresses?' She was concerned at first but she accepted it fairly quickly. In fact, it made us closer. You see, my family lost so much - not only in the war, but also during our struggles in the states. We have a very live-like-there's-no-tomorrow mentality. And, well, for good reason of course. For most members of my family, there has been, indeed, moments when tomorrow might have never come. Unlike many of my queer American brothers and sisters, for me, the difficulties of coming out were minimal compared to other traumas my family experienced-like bombs \& concentration camps. We have lived as if we shouldn't have been given a second chance, so it's hard to hold many reservations. Maybe this is why most of my family is also bankrupt. Like my grandmother used to say: 'Chơi xả láng, sáng về sớm!'

But Vương is also a contemplative soul who devotes himself to Buddhism. His spirituality has influenced and shaped his poetry: both in the process of writing, and in the way he views the world. As Vương puts it,

For Buddhists, the root of all suffering is desire itself. I accept the fact that I'm not a monk, that my life is too often dictated by even the most basic desires: a job, a house for my mother, so and so's new book, a man's body, quiet, open spaces. What I find nearly impossible to accept, however, is being both a Buddhist and a poet at the same time. Yes, other Buddhist poets like Jane Hirshfield and Gary Snyder, both of whose work I admire, have pulled it off. But for me, what's most problematic is the very desire to make poems 
Trangdai Glassey-Tranguyen- Articulating Refug-endity in VietnAmerica and the Diasporas

at all. As I write this, hundreds of monks in Tibet are being beaten, killed, and persecuted by the Chinese government. How can my poem make a difference there? It's hard to come to terms with my writing when the world is on fire and here I am, obsessing over a handful of paper.

Vương further contemplates,

Like this very body I possess, the act of writing is, to me, just a means of translation, a place to store the soul. What's more is that I have to face the fact that the poem will never be what I intended it to be-I can only get very close (if I'm lucky). I have to accept the fact that the very material I work with will ultimately fail me. Jack Gilbert perhaps said it most poignantly: 'Love, we say, God, we say, Rome and Michiko, we write, and the words get it wrong.' They do, they get it wrong, and still we get up, we try to love each other, to resist our incredible ability to be cruel, and we try, we work and we mine language until it satisfies our need to make something meaningful. But the trying is what I fear. I pick up the pen and think: 'Could I be doing something better with these hands?' As I fix the flaws of the poem, the flaws of a man stack up around me, often times unnoticed. This scares me more than anything: the idea that I will end up using this precious time on earth making poems very few people will read, while there is still so much I can do with this body I am given.

\section{"A Hapa Rap in Vietnamese"}

Of the discussion on young Vietnamese diasporic artists and writers, I would like to close with an homage to the late John Vietnam Nguyễn, whose lifetime motto has been "Know your roots." Both Ocean Vương and John Vietnam Nguyễn grapple with their Vietnamese identities, but in very different ways. Despite being born in the U.S., Nguyễn makes use of his ethnic language, while Vương feels a certain kind of reverence to it and does not want to "taint it." Nguyễn stays close to his roots, commemorating the fall of Saigon and straddling his ethnic heritage. Of the official culmination of the Vietnam War ${ }^{\text {xxxvi }}$, Nguyễn states,

April 30th, also known as Black April, symbolizes the Fall of Saigon and the end of the Vietnam War. Today we commemorate those who fled from, fought for, and lived through the war by wearing black as well as writing 'Saigon' or 'Sài Gòn' on our hands, wrists, and arms. For me, it is an acknowledgment of my roots, and a way to pay my respects where they are due.

The orality and aurality of John Vietnam Nguyễn conjures up a sense of home for an American-born rapper of Vietnamese descent, which he captures in his bilingual signature line, "One life, one love-Một đời, một tình yêu." Despite the abrupt conclusion of his young life when he drowned after rescuing a friend during a swim in Madison's Lake Mendota ${ }^{\text {xxxvii }}$, Nguyễn leaves a lasting legacy upon his communities at home, at school, and in the arts. His community erects a mural in his honor ${ }^{x x v i i i}$, and a street was named after him (Emmanuel, 2014; Schmich, 2014). In an inspirational email to friends, he expresses his strong conviction that: 
Trangdai Glassey-Tranguyen- Articulating Refug-endity in VietnAmerica and the Diasporas

Hip-hop isn't just something do, it's the way you live. Emceeing, or, rapping, isn't just a hobby. The values ingrained in hip-hop emerge in your behavior and attitude outside of the cypher or song. It's all about peace, love, unity, and having fun. Emceeing is a way to cope with problems in life; art is a result of suffering. Eventually with enough practice and inspiration, your art becomes something people relate to, because we all go through the same problems. You learn how to be a leader, not just when you're spitting, but when those crucial moments arise in life where you just need to step up. An emcee doesn' $t$ just spit. He has the hip-hop culture embedded in his genes. An emcee wouldn't sit back and ignore the problem. Tackle it directly. Emcees should look at grades like the cypher. Get in there. Do your thing the way it should be done. And come out knowing you did it right.

Nguyễn strongly believes in the potential of each individual, and the stories unique to each of us. He writes,

If you're serious about your flow, you have to practice. Do lyrical exercises. Write multisyllabic rhyme schemes for practice. Learn new words everyday. Freestyle everyday. Set a high standard for EVERYTHING you do. Never settle for less than perfect. If your flow is off, don't call it a finished work. Have an arsenal ready. at all times. If you're serious about recording. learn about the technical aspects of it. Don't ask for video games for Christmas or your birthday. Ask for a condenser microphone. Be more motivated than your peers. Be their inspiration. Understand that hard work is the road only known for success. If you have the inner drive and desire to be successful, then nothing will hold you back, and your light will eventually shine - this is where patience comes in. Regardless, hard work that comes straight from the soul is always recognized. Keep doing you. And tell your story. No gimmicks.

No gimmicks. That is how Nguyễn spends his short life on earth. I argue that his most daring act might have been his "A Hapa Rap in Vietnamese," performed in Vietnamese with bilingual captions. The Vietnamese lyrics that I transcribed from Youtube video ${ }^{\text {xxxix }}$ reads:

\author{
thành phố Chicago 773 \\ nghe thử \\ cái gì mình đi lên \\ cũng phải đi xuống \\ không bao giờ mình có \\ những gì mình muốn \\ chúng ta biết hạnh phúc ở đâu mà kiếm \\ trên đời này người tốt là hiếm \\ người ta nói nhiều chuyện \\ muốn mình nghề có lương cao \\ bài hát này là của mình \\ người ta nghĩ là tự cao \\ nghe rõ
}


Trangdai Glassey-Tranguyen- Articulating Refug-endity in VietnAmerica and the Diasporas

\author{
mấy câu tôi nói vì dễ nhớ \\ đây là câu chuyện giữa một người Việt và một người Mỹ đó \\ tôi nghĩ \\ cuộc đời khi đẹp khi xấu đó \\ sao thù hận nhau chúng ta cùng dòng máu đỏ \\ nô lệ của xã hội \\ chúng ta chưa có tự do \\ mọi người bị đói kiến thức \\ mọi người chưa được ăn no \\ mời các bạn \\ nghe thử lời này \\ không có gì dễ ở trên đời này \\ người ta hỏi hoài \\ tôi sống ở đâu \\ (“where're you from?") \\ mà nếu mà biết đi ở đâu trước \\ đừng hỏi gì hết \\ đừng nói gì hết \\ khi tôi không nói gì hết \\ là tôi đã chết
}

\title{
The Coming Crops of Bilingual Refug-endity
}

Here, I choose not to discuss Nguyễn's Vietnamese language command, but focus on his innovative blend of his mother tongue and the rap beats. Nguyễn's bold use of Vietnamese in his rap gives us reasons to believe in the important role that the Vietnamese language continues to play in the life and arts of Vietnamese diasporic-born generation. With new development in Vietnamese English dual immersion programs in public education at all levels from K (GlasseyTranguyen, 2014g) through college (Glassey-Tranguyen, 2013d), it is possible that in the future, we will have many more bilingual writers and artists who comfortably, proudly, and fluently straddling the English and Vietnamese lingo worlds. The articulations and expressions Vietnamese diasporic refug-endity will surely be not only in non-Vietnamese languages but bilingual.

With this, the new crops of diasporic arts are becoming ever-more globalized, and the bilingual creatives of the future will not only be celebrated in the diasporas and around the world, but can be fully appreciated back in the country of ethnic origin Vietnam. I have argued elsewhere (Glassey-Tranguyen, 2015) that owing to the interactions and mutual influences between Vietnam and its diasporas, Vietnam is diasporic and the diasporas are Vietnam. As a borderless medium, creative arts can further connect Vietnam with its diasporas and vice versa, as well as engaging with non-Vietnamese people across geographical distances and forging new identities and conversations. Ethnic Vietnamese artists and their audiences alike in the diasporas can continue to stay connect with their roots and be inspired to search for their identity-a continuation surely gestures toward new seasons of artistic expressions of refug-endity. Through these practices, diasporic Vietnamese generations can document and transform the past through remembrance and/or with their own makings like Ocean Vương. Here in 2015, we have the rare 
Trangdai Glassey-Tranguyen- Articulating Refug-endity in VietnAmerica and the Diasporas

privilege of looking back at the forty years of Vietnamese diasporas formation and arts making, from the first creative works published in Vietnamese in 1975-Orange-County to the latest creative works just emerge in the diasporas today. Generations of ethnic Vietnamese artists have committed to their creative call and dedicated to documenting their experiences through the arts, and by so doing have helped to continue the expression of, the search for, and the honoring of the Vietnamese diasporic experience - a legacy that will be passed on to future generations as to help keep them connected to their roots.

\section{Endnotes}

${ }^{\mathrm{i}}$ I thank the JSAEAA reviewers for their valuable comments on the first draft; the JSAEAA editors Dr. Wayne Wright, Marshall Klassen, and Bryan Thao Worra for working with me on this entry; and Olivier GlasseyTranguyen for proofreading and providing inputs on the revisions. Special thanks to Marshall Klassen for working with me on the specificities of Vietnamese names and APA formatting.

${ }^{i i}$ See, for instance, Tranguyen, 2004b. See also Poets in VietnAmerica publications and events since the 1990s till today.

iii There are certainly oppositions and competitions in literary VietnAmerica, like in any literary environment. Since the focus here is on autonomy, I will explore the tensions and gatekeeping in another publication.

${ }^{i v}$ Here, I focus on "relevant" rather than "important" texts for two reasons. First, there has not been a comprehensive study of Vietnamese-language diasporic literature since 1975, hence I wish to keep open the discussion on which texts should be considered "important." Second, my entry is not a survey of this body of works, but focuses on how it has helped define refug-endity in VietnamAmerica and the diasporas.

${ }^{v}$ Since I began oral history research in the 1990s, I consciously chose to conduct oral history interviews using the biographical approach instead of the thematic abridged format. While this approach is much more time demanding and labor intensive, it allows me to get at deeper narratives and ask follow-up questions that open up nuances and detours. I have observed that the biographical approach is not only useful, but crucial in enabling me to get in-depth information when the meeting time with an informant was limited.

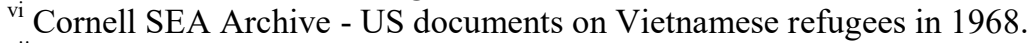

vii In this book, which won the National Prize of the Republic of South Vietnam in 1969, Nhã Ca recounts her experiences being on the ground in Huế during the Việt Cộng assaults during the 1968 Lunar New Year. The book was republished in 2008 by Việt Báo Daily News, and has been translated in to English by Olga Dror, Indiana University Press, 2014.

viii Vietnamese original:

Phượng nhìn xuống vực thẳm.

Hà Nội ở dưới ấy.

Từ chỗ anh đứng, Phượng nhìn sang bờ đường bên kia. Những tảng bóng tối đã đặc lại thành khối hình. Từng chiếc một, những hàng mái Hà Nội nhoà dần. Phượng nhìn lên những hàng mái cũ kỹ், đau yếu ấy, giữa một phút giây nhoè nhạt, anh cảm thấy chúng chứa đựng rất nhiều tâm sự, rất nhiều nỗi niềm. Những tâm sự câm lặng. Những nỗi niềm nghẹn uất. Của Hà Nội. Của anh nữa.

Dưới những hàng mái cong trũng, ngập đầy lá mùa kia, đang xảy ra những tâm trạng, những biến đổi gì mà ở bên này đường Phượng không đoán hiểu được. Hà Nội đang đổi màu. Đứng bên này bờ đường nhìn sang, Phượng bắt đầu tiếp nhận với một thứ cảm giác ớn lạnh, cách biệt, anh đã đứng trên một bờ vĩ tuyến mà nhìn về một vĩ tuyến bên kia. Bên ấy, có những hình ảnh chia cắt, đứt đoạn. Bên ấy, có những hình chiến luỹ, những hàng rào dây thép gai, những đoạn đường cấm, những vùng không người.

Phượng cũng không hiểu tại sao nữa. Giờ này anh còn là người của Hà Nội, thở nhịp thở của Hà Nội, đau niềm đau của Hà Nội, mà Hà Nội hình như đã ở bên kia.

${ }^{\mathrm{ix}}$ Vietnamese original:

Đứng một mình trong đêm dài, trước một Hà Nội ngủ thiếp, Phượng nghĩ đến những người bạn đường đã vượt Hồng Hà, đã bỏ Hà Nội, bỏ đất Bắc trước anh, vượt vĩ tuyến về tiếp tục cuộc đấu tranh cho tự do, cho con người, trên phần đất nước còn lại. Anh biết rằng thời đại, trong ngày tới sẽ nối kết con người bằng một ý niệm một hệ thống tự do. Tâm trạng của Phượng đêm nay cũng là tâm trạng của một người thợ máy Đức, một người dân cầy Triều Tiên, đang 
Trangdai Glassey-Tranguyen- Articulating Refug-endity in VietnAmerica and the Diasporas

ngày đêm vượt khỏi những vĩ tuyến tù đày để tìm một hướng đi, một chân trời có không khí và ánh sáng.

${ }^{x}$ There is a differentiation between the words "refugee" and "immigrant" in the Vietnamese migration history since April 1975. For those leaving as evacuees during or right after April 30, 1975, as well as the boat people thereafter through the early 1990s, the term "refugees" has often been used and given more historical and political import than the term "immigrants," with an implied deserving legitimacy. For the subsequent waves - those sponsored by family members or the HO Humanitarian Operation that brings former political detainees of the ARVN to the U.S. - they are called "immigrants," sometimes with a lesser level of legitimacy. There are also international students from Vietnam, entrepreneurs, artists or other professionals, picture brides, etc... This differentiation fails to acknowledge the complexity of migration processes, and glosses over the fact that even long after a war has ended, there can still be "refugees" who have been persecuted all this time in their home country, such as the political detainees. Here, I use the two words with a mindfulness of how they belie all the historical and contextual underpinnings of migration from Vietnam, and against the convenient binary traditionally associated with the two terms.

${ }^{x i}$ I have argued elsewhere that Vietnam is also part of the diasporas and vice versa. See, for instance, GlasseyTranguyen, 2015.

${ }^{x i i}$ For more information on VAP, please refer to: Tranguyen, 2004b. An earlier version of this article won the 2013 CSUF Student Research Competition, and the championship at the 2003-04 CSU System $18^{\text {th }}$ Annual Student Research Competition in the category of Humanities \& Letters, Graduate level.

xiii While some in VietnAmerica oppose Trịnh Công Sơn as a Communist collaborator and disregard his music, Trịnh"s songs have been well-appreciated by many generations since the Vietnam War era.

xiv The late Nguyễn Đức Quang was the founder of Viễn Đông Daily News, one of the three major Vietnameselanguage newspapers in Orange County. Born February 11, 1944 in Sơn Tây, North Vietnam, Nguyễn had émigrated South with his family in 1954 following the Geneva Accord. A music prodigy, he is widely-known and well-loved in his homeland Vietnam and across the Vietnamese diasporas. Nguyễn"s songs touch the deepest corners of human hearts, especially his placenta fellows across time and space. Nguyễn served in the Army of Republic Vietnam prior to 1975, underwent re-education camps thereafter, escaped by boat, and eventually resettled in America. Bilingual biography prepared by Glassey-Tranguyen for and published in the bilingual program book of "Vết Thương Vô Diện, Hòa Bình Vô Danh - Faceless Wounds, Nameless Peace."

${ }^{x v}$ Trần Mộng Tú is a poet, writer, and the former Editor-in-chief of the monthly journal Phụ Nữ Gia Đình, a subpublication of Người Việt Daily. A contributor to Vietnamese literary magazines throughout the world since 1975, she has also published many works including "Thơ Trần Mộng Tú" (Người Việt, 1990), "Câu Chuyện của Lá Phong" (Thế Kỷ, 1994), "Để em làm gió" (Thế Kỷ, 1996), and "Cô Rơm và Những Truyện Ngắn" (Văn Nghệ, 1999). Her poems are also anthologized in Dream of Peace (Warner Books, 1990), Anthology of Vietnamese Poems from the Eleventh through the Twentieth Centuries (Yale University Press, 1996), and American Literature textbook (Glencoe/McGraw-Hill, 1999). Bilingual biography prepared by Glassey-Tranguyen for and published in the bilingual program book of Vết Thuơng Vô Diện, Hòa Bình Vô Danh - Faceless Wounds, Nameless Peace.

${ }_{\text {xvi }}$ I attain this perspective through my two decades of life in post-1975 Vietnam and two decades of research on the Vietnamese diasporas across the four continents.

xvii I describe the forced alteration of the Vietnamese language upon the 1975 takeover of the South as "murder" because it aims at erasing not just the existing language, but to eradicate any intellectual and cultural strata in the South prior to the takeover. Though the new regime does not declare a Vietnamese language reform - as in the case of land reform, education reform, etc - the domination of the Northern government works to replace all that has existed in Southern Vietnam before their invasion.

xviii The Vietnamese people would commemorate the deaths of loved ones at least three years after their passing on the day of their death, a custom called "ngày giỗ" or an anniversary.

${ }^{x i x}$ This observation is made with my full awareness of the slippage of memory and the complexity in recalling past events. See, for instance, Tranguyen 2004band 200b. See also the second half of this entry.

${ }^{\mathrm{xx}}$ Vietnamese original:

Quyển sách này không thể là một tác phẩm tiểu thuyết văn chương, cũng không thể nằm trong hình thức một hồi ký chính trị hoặc một bút ký lao tù. Quyển sách này, thực tế, chỉ có thể được coi như một đống quặng mỏ, được khai quật và còn giữ nguyên hình thái chân thực của nó. Hoặc có thể nói một cách khác, bảy mươi chương sách này có thể xem như bảy mươi tấm ảnh, được chụp liên tục và được rửa ra bởi một phó nháy may mắn và có tính tiếc của, nháy được bảy mươi hoàn cảnh buồn nhưng có ý nghĩa trong đời tù cải tạo dưới chế độ cộng sản. Hoặc có thể nói một cách khác hơn nữa, quyển sách này là bản phúc trình của một người lính VNCH bị bỏ rơi, bị ở tù cộng sản, rồi 
Trangdai Glassey-Tranguyen- Articulating Refug-endity in VietnAmerica and the Diasporas

thoát được ra ngoài, ngồi viết lại để kính gửi tới những ai còn thương yêu và còn quan tâm đến nước Việt Nam và con người Việt Nam còn ở lại...

xxi There are numerous efforts to document the Vietnamese boat people experiences, including Project Ngọc at UC Irvine, Văn Khố Thuyền Nhân - Vietnamese Boat People Archive in Australia, the Southeast Asian archives at Cornell University, and the like.

xxii Statues of Vietnamese boat people such as those in Canada and Australia, as well as monuments in appreciation of the host countries such as those in Hamburg, Germany, have been built over the years with annual events commemorating this part of Vietnamese refug-endity worldwide.

xxiii Here, I use the word "interpret" as both "to translate" and "to bring new understanding."

xxiv I put the word "traditional" in quotation marks to indicate that no culture exists in isolation, hence it is impossible to claim cultural authenticity when it comes to Vietnam, known as "the balcony of the Pacific Ocean," which has constantly interacted with non-Vietnamese forces since the beginning. Therefore, even something identified as "traditionally Vietnamese" today is likely to have been a hybrid, like the Vietnamese áo dài which has a Chăm origin.

${ }^{\mathrm{xxv}} \mathrm{http}: / / \mathrm{www} . v i e t n a m e s e m u s i c . u s /$

${ }^{x x v i}$ While Underhill belongs to the younger diasporic generation, I believe the discussion of her work fits better in this section because of the theme on cultural preservation and ethnic autonomy. In many ways, Underhill is very autonomous and within the ethnic Vietnamese diasporas, her voice as a Chăm ethnic champions the struggles for recognition and inclusion of indigenous and minority peoples in and outside of Vietnam.

${ }^{x x v i i}$ There are several other writers whose works are also relevant, but owing to the limit of space, I am unable to include here. See, for instance, Lan Cao's Monkey Bridge (1997 Viking Penguin) and The Lotus and the Storm (2014 Viking Press); lê thị diễm thuý's The Gangster We're All Looking For (Knopf, 2003); Monique Trương's Book Of Salt (2003 First Mariner books) and Bitter In The Mouth (2010 Random House); Kim Thuy's Ru (2012 Random House Canada); etc.

xxviii Howard Vũ invited me to help him review and edit the bilingual script, leading to my involvement in the making of the film as casting director, dialect coach, and on-site translator. I was present throughout the filming period to provide support, expertise, and feedback.

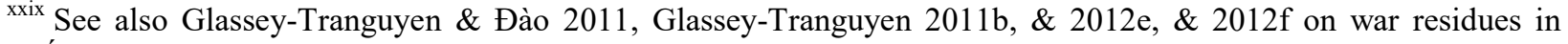
Thắng Đào's integration of Vietnamese music and ballet.

${ }^{\mathrm{xxx}}$ Bình Danh. Project: "Immortality, The Remnants of the Vietnam and American War." binhdanh.com.

xxxi Danh Võ. "Go Mo Ni Ma Da," May 24 - August 18, 2013. Musée D'Art Moderne de La Ville de Paris. http://www.mam.paris.fr/en/expositions/danh-vo.

xxxii Journey from the Fall wins several awards, including the Best Cinematography at the Milano International Film Festival, the Best Feature Film at Anchorage International Film Festival, the Grand Jury Prize at Amazonas International Film Festival in Brazil, among others.

xxxiii Hàm Trần's other films include: Ngày Giỗ/The Anniversary (2004), Pomegranate (2002), Parents (2002), The Prescription (2001), Poetree (2000), and Sisyphus (2000).

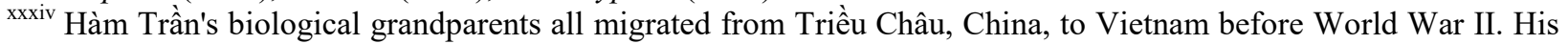
paternal grandmother passed away when his father was 16 . His paternal grandfather later married a Vietnamese woman from Vĩnh Long. It is his step-grandmother that has the most influence on Trần's Vietnamese enculturation.

xxxv See, for instance, Việt Hồ Lê, "The Death of Marat," silver print.

${ }^{x x x v i}$ I have maintained that the Vietnam War is still on in many ways, albeit its official military ending in April 1975. See, for instance: Glassey-Tranguyen, 2008.

xxxvii Richardson 2012. News stories did not say that Nguyễn drowned after rescuing a friend, but his friends bore witness of his heroic act.

xxxviii John Vietnam Nguyen's Memorial Mural x Heaven: http://www.youtube.com/watch?v=ngYhkh4n5pk.

${ }^{x x x i x}$ https://www.youtube.com/watch?v=V3U-hqQ3kGo. Accessed 6/30/2014. 
Trangdai Glassey-Tranguyen- Articulating Refug-endity in VietnAmerica and the Diasporas

\section{References}

\section{Notes:}

All authors' names follow APA citation format, with the exception of retention of the author's full name, and special consideration for names marked with an asterisk. These names are kept in their Vietnamese originals for recognition and to preserve their dignity. In the Vietnamese literary convention, the pen name can be of the author's own creation, such as Hàn Mạc Tử; or after the author's hometown, such as Đông Bàn; or a derivative of the author's full name, such as Vũ Ánh (from Vũ Văn Ánh); or the author's legal name, such as Nguyễn Xuân Hoàng (in Vietnamese order: surname, middle name, given name). Some names also come with a prefix to indicate an honorific title or a Buddhist name. Moreover, some historically prominent families are recognized by not only their surnames, but also their middle names. Given the diverse nature of Vietnamese pen names and to optimize recognition across the languages, I choose to keep intact the Vietnamese names of authors whose publications are primarily or only in the Vietnamese. Most importantly, the order of a pen name (even when it is identical to the legal name) should not be changed, and none of its parts should be in initials - or it will not be recognizable to readers. For instance, no one would make the connection between "Vũ, Á." and Vũ Ánh if we were to follow the APA style. I observe that several English academic publications have retained the original order of Vietnamese authors (such as "Nguyễn Du" or "Hồ Xuân Hương"). In my own work, I have retained the Vietnamese practices of names to strive for cultural appropriateness and to allow the readers to identify the authors properly.

For the Vietnamese-language sources cited, not all information is available, such as the city of publication. This is due to the informal undocumented nature of community-based publications, especially those printed in the 1980s and 1990s. I spent several weeks searching in vain for some of the information on the Vietnamese publications, especially for the city. Even a publisher is 'transient' because it is often housed at the residence of a writer in a writing group, and if the editor role is passed on to someone else, then the publisher is 'moved.' Moreover, several publishers/writers have passed away, and records of their residences while they served as publishers are not kept and are also private information. Many pieces of information can't be found even on the actual copy of a book. "N/A" indicates where the information is unavailable.

Cao, Lan. (1997). Monkey Bridge. New York, NY: Viking Penguin. Cao, Lan. (2014). The Lotus and the Storm. New York, NY: Viking Press.

Danh, Bình. (2005). Immortality, The Remnants of the Vietnam and American War. Retrieved from http://binhdanh.com/Projects/Immortality/Immortality.html

*Du Tử Lê. (1987). "Cám ơn Pendleton” in Tho Tình. Tủ Sách Văn Học Nhân Chứng Publishing.

Đỗ, Khoa. (Producer), \& Manning, Jane (Director). (2001). Delivery Day [Short Film]. Australia: Porchlight Films.

Đỗ, Khoa. (Director). (2006). Footy Legend [Feature Film]. Australia: Megan McMurchy.

Đố, Khoa. (Director). (2010). Mother Fish [Feature Film]. Australia: Imaginefly.

*Đỗ Văn Phúc. (2008). Cuối Tầng Địa Ngục. Houston, TX: Vietland Publishing. 
Trangdai Glassey-Tranguyen- Articulating Refug-endity in VietnAmerica and the Diasporas

Emmanuel, A. (2014, March 17). Rapper John 'Vietnam' Nguyen honored with street name in Uptown. Retrieved from http://www.dnainfo.com/chicago/20140317/uptown/rapperjohn-vietnam-nguyen-honored-with-street-name-uptown

Glassey-Tranguyen, Trangdai, \& Đỗ, Khoa. (2009, April 3). Biographical oral history interview/Interviewer: Trangdai Glassey-Tranguyen. Vietnamese Diasporas Project, Santa Ana, CA.

Glassey-Tranguyen, Trangdai, \& Trần, Hàm. (2011). Biographical oral history interview/Interviewer: Trangdai Glassey-Tranguyen. Vietnamese Diasporas Project, Anaheim, CA.

*Glassey-Tranguyen, Trangdai, \& Du Tử Lê. (2002, February 2). Biographical oral history interview/Interviewer: Trangdai Glassey-Tranguyen. Vietnamese American Project, Center for Oral \& Public History, CSU Fullerton, Garden Grove, CA.

Glassey-Tranguyen, Trangdai, \& Levan, Simon. (2000, January 9). Biographical oral history interview/Interviewer: Trangdai Glassey-Tranguyen. Vietnamese American Project, Center for Oral \& Public History, CSU Fullerton, Westminster, CA.

*Glassey-Tranguyen, Trangdai, \& Phạm Phú Minh. (1999, December 15). Biographical oral history interview/Interviewer: Trangdai Glassey-Tranguyen. Vietnamese American Project, Center for Oral \& Public History, CSU Fullerton, Westminster, CA.

Glassey-Tranguyen, Trangdai, \& Nguyễn, Paul. (2000, April 7). Biographical oral history interview/Interviewer: Trangdai Glassey-Tranguyen. Vietnamese American Project, Center for Oral \& Public History, CSU Fullerton, Westminster, CA.

Glassey-Tranguyen, Trangdai, \& Nghiêm, Đại Đạo. (2000, November 19). Biographical oral history interview/Interviewer: Trangdai Glassey-Tranguyen. Vietnamese American Project, Center for Oral \& Public History, CSU Fullerton, Pittsburgh, PA.

Glassey-Tranguyen, Trangdai, \& Phong, Ann. (2000, May 7). Biographical oral history interview/Interviewer: Trangdai Glassey-Tranguyen. Vietnamese American Project, Center for Oral \& Public History, CSU Fullerton, Cerritos, CA.

Glassey-Tranguyen, Trangdai, \& Đào, Thắng. (2011). Biographical oral history interview/Interviewer: Trangdai Glassey-Tranguyen. Vietnamese Diasporas Project, Columbia University/Manhattan, NY.

Glassey-Tranguyen, Trangdai, \& Vũ, Thiênnũ̃. (2000, August 12). Biographical oral history interview/Interviewer: Trangdai Glassey-Tranguyen. Vietnamese American Project, Center for Oral \& Public History, CSU Fullerton, San Francisco, CA.

Glassey-Tranguyen, Trangdai. (2008). (Women) Civilians after wars: Any nation state asking for their forgiveness?. in D. White \& S. Schulman (Eds.), Forgiveness: Probing the boundaries (pp. 223 - 229). United Kingdom: Inter-Disciplinary Press.

Glassey-Tranguyen, Trangdai. (2011a). Biển-đời: ann phong và nguyễn việt hùng trong những sáng tạo mới [Art critique of Tandem-Solo Exhibit of latest works by Ann Phong and Nguyễn Việt Hùng]. Westminster: Người Việt Daily Community Room.

Glassey-Tranguyen, Trangdai. (2011b). Tam Bảo của tôi: Ba tập thơ Thiền song ngữ của Nguyên Giác Phan Tấn Hải [Review of set of three bilingual Zen poetry books compiled and annotated by Phan Tấn Hải entitled Lời Day Từ Các Thiền Su Việt Nam Xưa - Teachings From Ancient Vietnamese Zen Masters; Trần Nhân Tông, Đức Vua Sáng Tổ Một Dòng Thiền - Trần Nhân Tông: The King Who Founded A Zen School; and The Wisdom Within - Teachings And Poetry Of The Vietnamese Zen Master Tuệ Trung Thuợng Sĩ]. Thư Viện 
Trangdai Glassey-Tranguyen- Articulating Refug-endity in VietnAmerica and the Diasporas

Hoa Sen. Retrieved at http://thuvienhoasen.org/a12436/tam-bao-cua-toi-ba-tuyen-tapthien-thi-song-ngu-cua-cu-si-nguyen-giac.

Glassey-Tranguyen, Trangdai. (2011c). Mother Fish - Cá Mẹ: Tâm Thức Việt giữa dòng Thế Giới Hiện Đại [Review of the film Mother Fish, by K. Đỗ].

Glassey-Tranguyen, Trangdai. (2011d, August 6). Căn Nhà Ngói Đỏ: Nguyễn Xuân Hoàng giữa

Trập trùng Tiềm thức [The Red-roofed House: Nguyễn Xuân Hoàng amid the Waves of Subconsciousness] [Review of the book Căn Nhà Ngói Đỏ [The Red-Roofed House] by Nguyễn Xuân Hoàng]. Diễn Đàn Thế Kỷ Magazine. Retrieved at http://www.diendantheky.net/2011/08/can-nha-ngoi-o-nguyen-xuan-hoang-giua.html.

Glassey-Tranguyen, Trangdai. (2011e). Thụ Phấn: Một mảng Lịch sử Việt Nam trong Vũ điệu

Ballet [Review of ballet performance entitled Quiet Imprint - Vết Lăn Trầm by Thắng Đào].

Glassey-Tranguyen, Trangdai. (2012a). "Một năm xa Người-Nhạc-Sĩ Hát-Mãi-Vì-Yêu Nguyễn Đức Quang." Sống Weekly.

Glassey-Tranguyen, Trangdai. (2012b). Đường Phía Bắc:' Mảng lịch sử câm nín. [Book Review of Đường Phía Bắc by Lê Đại Lãng]. Houston: Trẻ Weekly.

Glassey-Tranguyen, Trangdai. (2012c). Đời sống tuần hoàn: Triển lãm tranh \& ảnh nghệ thuật. [Art exhibition review]. Santa Ana: VAALA.

Glassey-Tranguyen, Trangdai. (2012d). Hàm Trần: Màn Bạc và Đời Thường [Hàm Trần: Silver

Screen and Real Life][Special Feature]. Việt Báo Xuân - 2012 Annual Spring Anthology.

Glassey-Tranguyen, Trangdai. (2012e, February 14). Thắng Đào, Vũ Điệu Ballet, Lịch sử Da

Vàng[Thắng Đào, Ballet, and Yellow History]. Retrieved from http://www.dutule.com/D_1-2_2-94_4-4100/trangdai-glassey-tranguyen-thang-dao-vudieu-ballet-lich-su-da-vang.html

Glassey-Tranguyen, Trangdai. (2012f). "Trái tim nghệ thuật Thắng Đào" [The Heart of Thắng

Đào’s Art][Special Feature]. Việt Báo Xuân - Annual Spring Anthology, 2012.

Glassey-Tranguyen, Trangdai. (2013a). Cũng Cần Có Nhau: Bản-lề Hoàng Xuân Sơn [In Need of Each Other: Hoàng Xuân Sơn The Hinge]. [Book Review of Cũng Cần Có Nhau by Hoàng Xuân Sơn]. Gió O. Retrieved at http://www.gioo.com/TrangDai/TrangDaiGlasseyTranguyenHoangXuanSon.htm.

Glassey-Tranguyen, Trangdai. (2013b). Tự Lực Văn Đoàn: Tám mươi năm sau càng rực rỡ. [Conference Review of "Hội Thảo và Triển Lãm Tự Lực Văn Đoàn”]. Người Việt Daily Community Room, Westminster, CA.

Glassey-Tranguyen, Trangdai. (2013c). "Việt Hồ Lê: Một Nghệ Sĩ toàn cầu đa năng, đa dạng - A Protean Global Artist." Bilingual Interview in 2009 \& 2014. Sáng Tạo. Retrieved at http://sangtao.org/2013/04/15/viet-ho-le-mot-nghe-si-toan-cau-da-nang-da-dang/.

Glassey-Tranguyen, Trangdai. (2013d, July 17). Bilingual public address as a Fulbright Scholar, Media Representative, and Founder/Director of Vietnamese Diasporas Projects. Presentation given at CSU Fullerton's Vietnamese community education night to introduce three Vietnamese programs, Garden Grove, CA.

Glassey-Tranguyen, Trangdai. (2013e, October 12). Sụ Thật Âm Lòng về Phan Nhật Nam [The Heart-warming Truth about Phan Nhật Nam]. Keynote presented at Book Release of Phận Người, Vận Nước [A Person's Lot, A Country's Life (my translation)] by Phan Nhật Nam, Little Saigon, CA. 
Trangdai Glassey-Tranguyen- Articulating Refug-endity in VietnAmerica and the Diasporas

Glassey-Tranguyen, Trangdai. (2014a, December 6). 40 Năm Văn Học Miền Nam Thất Thủ: Thế hệ Hậu Chiến khước tù Thân phận Mồ côi [Forty Years After the Siege of South Vietnam's Literature: The Postwar Generations Refuse the Orphan Lot]. Presented at the conference Văn Học Miền Nam 1954-1975, Orange County, CA.

Glassey-Tranguyen, Trangdai. (2014b, July 19). Thung Lũng Tủ Thần: Hit Thở Bóng Tối Hy Vong Với Vũ Ánh [The Valley of Death: Breathing the Darkness of Hope with Vũ Ánh]. Keynote presented at posthumous book release and book review at Người Việt Daily News Community Room, Westminster, California.

Glassey-Tranguyen, Trangdai. (2014c). Chuyện kể bên bàn cơm: Tái thiết quá khư với Đạo diễn Khoa Đô̂/Interviewer: Trangdai Glassey-Tranguyen. Da Màu, Santa Ana.

Glassey-Tranguyen, Trangdai. (2014d). "Race/class/gender in the eye and life of director khoa đỗ: a perspective in film - sắc tộc/giai cấp/giới tính trong cái nhìn điện ảnh và cuộc đời của đạo diễn khoa đỗ." Bilingual Interview in Santa Ana, CA (Oral history interview in English, Vietnamese rendition by GTT). Online Magazine: Da Màu.

Glassey-Tranguyen, Trangdai. (2014e). "Ann-phong tại ann-home: ngọn gió nghệ thuật việt tại anaheim." [Art critique of Ann Phong's solo exhibition, Anaheim, CA]. Sáng Tạo. Retrieved at http://sangtao.org/2014/02/05/ann-phong-tai-ann-home-ngon-gio-nghethuat-viet-tai-anaheim/.

Glassey-Tranguyen, Trangdai. (2014f). "Ocean Vương: Tales of Disjunctured Homes - Câu Chuyện của Những Mái Ấm Đứt Đoạn.” Interview in English with Vietnamese version by TGT. Westminster, CA: Viễn Đông Daily News.

Glassey-Tranguyen, Trangdai. (2014g, February 18). A Fulbright Perspective on Advocacy for Vietnamese-English Dual Immersion Education. Public address presented at Garden Grove Unified School District Board Meeting, Garden Grove, California.

Glassey-Tranguyen, Trangdai. (2015). "Home in Stockholm: Vietnamese Diasporic Narratives of Transnationalism" in Quan Tran, Thu-Huong Nguyen-Vo, \& Mariam B. Lam (Eds.), Routes of Engagement: Việt Nam and Diasporas. Oxford, UK: Routledge.

*Hà Thúc Sinh. (1985). Đại Học Máu: Chuyện kể về 1685 ngày tù duới chế độ Cộng sản Việt Nam (The Blood University: Accounts of 1685 Days of Incarceration under Vietnamese Communist Regime). N/A: Nhân Văn Publishing.

*Hoàng Xuân Sơn. (2013). Cũng Cần Có Nhau [In Need of Each Other]. Canada: Nhân Ảnh Publishing.

Kim Thuy. (2012). Ru. Montreal, Canada: Random House Canada.

*Lê Đại Lãng. (2012). Đường Phía Bắc. Houston, TX: Trẻ Publishing. lê thị diễm thuý. (2003). The Gangster We're All Looking For. Knopf, 2003);

*Nam Lộc. (1975). "Vĩnh Biệt Sài Gòn.” Music Score/Song in Vietnamese.

*Mai Thảo. (1955). Đêm giã tù Hà Nội. Sài Gòn, Vietnam: Người Việt Publishing.

Nguyen, J. V. [John Vietnam]. (2012, December 9). John Vietnam Memorial Mural $x$ Heaven.[video file]. Retrieved from http://www.youtube.com/watch? $=n g Y h k h 4 n 5 p k$

Nguyen, L. \& Tran, H. (Producer), \& Tran, H. (Director). (2007). Journey from the Fall [Motion Picture]. United States: ImaginAsian Pictures.

*Nguyên Giác Phan Tấn Hải. (2010a). Lời Dạy Tù Các Thiền Su Việt Nam Xưa - Teachings From Ancient Vietnamese Zen Masters. Escondido, CA: Thiền Tri Thức Publishing. 
Trangdai Glassey-Tranguyen- Articulating Refug-endity in VietnAmerica and the Diasporas

*Nguyên Giác Phan Tấn Hải. (2010b). The Wisdom Within - Teachings And Poetry Of The Vietnamese Zen Master Tuệ Trung Thương Sĩ. Escondido, CA: Thiền Tri Thức Publishing.

*Nguyên Giác Phan Tấn Hải. (2010c). Trần Nhân Tông, Đức Vua Sáng Tổ Một Dòng ThiềnTrần Nhân Tông: The King Who Founded A Zen School. Escondido, CA: Thiền Tri Thức Publishing.

*Nguyễn Thanh Nga. (2007). Đoá Hồng Gai. Westminster, CA: Việt Tide Magazine Publishing. Nguyễn, Thuyết Phong. (1995). Searching for a Niche: Vietnamese Music at Home in America. Kent, OH: Viet Music Publications.

*Nguyễn Xuân Hoàng. (1989). Căn Nhà Ngói Đỏ. Westminster, CA: Văn Nghệ Publishing.

*Nguyễn Xuân Hoàng. (1992). Bụi và Rác. Westminster, CA: Thanh Văn Publishing.

*Nhã Ca. (2008). Giải Khăn Sô cho Huế. Westminster, CA: Việt Báo Daily News Publishing.

*Nhã Ca. \& Olga, D. (1968). The Mourning Headband for Huế: An account of the battle for Huế, Việt Nam 1968. Indiana: Indiana University Press.

*Phạm Xuân Đài. (1994). Hà Nội trong mắt tôi. Westminster, CA: Thế Kỷ Publishing. *Phan, Nhật Nam. (2013). Phận Ngươi, Vận Nước. Westminster, CA: Sống Publishing.

Richardson, B. (2012, September 13). Gifted young hip-hop artist dies in apparent drowning. Poet was just about to start his sophomore year of college. WBEZ91.5. Retrieved from http://www.wbez.org/sections/art/gifted-young-hip-hop-artist-dies-apparent-drowning102416

Schmich, M. (2014, March 19). Hip-hop artist John Vietnam remembered on Argyle. Chicago Tribune. Retrieved from http://articles.chicagotribune.com/2014-03-19/news/ct-schmich0319-20140319 1 argyle-street-street-sign-little-vietnam

*Trầm Tử Thiêng. (1969). "Kinh Khổ." Music Score/Song in Vietnamese.

*Trầm Tử Thiêng. (1991). "Bên Em Đang Có Ta." Music Score/Song in Vietnamese.

*Trầm Tử Thiêng. (1996a). "Một Đời Áo Mẹ Áo Em.” Music Score/Song in Vietnamese.

*Trầm Tử Thiêng. (1996b). "Một Ngày Việt Nam.” Music Score/Song in Vietnamese.

*Trần Mộng Tú. (1990a). Tho Trần Mộng Tú. Westminster, CA: Người Việt Publishing.

*Trần Mộng Tú. (1990b). Câu Chuyện Của Lá Phong. Westminster, CA: Thế Kỷ Publishing.

*Trần Mộng Tú. (1996). Cô Rơm và Nhũng Truyện Ngắn. Westminster, CA: Văn Nghệ Publishing.

*Trần Mộng Tú. (1996). Để Em Làm Gió. Westminster, CA: Thế Kỷ Publishing.

*Trần Mộng Tú. (2009). Tho Tuyển Bốn Muơi Năm 1969-2009. (poetry chapbook). Seattle, WA: Self-published.

Tranguyen, Trangdai. (2004a). "Orange County, Yellow History: An Intimate Encounter with Vietnamese American Lives." In T. J. Fusciano (Ed.), Journal of the Society of American Archivisits, 2(4), 5-28.

Tranguyen, Trangdai. (2004b). Faceless Wounds, Nameless Peace - Vết Thưong Vô Diện, Hoà Binh Vô Danh. Bilingual book for the multi-genre cross-disciplinary bilingual program entitled concelebrating CSU Fullerton's Asian heritage month and Vietnamese Orange County's Black April Commemoration at Người Việt Daily News, Community Room, Westminster, CA. Fullerton, CA: Center for Oral \& Public History.

*Trịnh Công Sơn. (N/A). "Ngày Mai Em Đi." Music Score/Song in Vietnamese.

Trương, Monique. (2003). Book Of Salt. First Mariner Books.

Trương, Monique. (2010). Bitter In The Mouth. Random House. 
Trangdai Glassey-Tranguyen- Articulating Refug-endity in VietnAmerica and the Diasporas

Võ, Danh. (2013). Mother Tongue [Mixed Media and Installation]. New York, NY: Metropolitan Museum of Art.

Võ, Danh. (2010-2014). We the People [International Installation Project]. New York, Chicago, and others: Public spaces, private galleries, and parks.

Võ, Danh. (2013). Go Mo Ni Ma Da [Mixed Media and Installation]. Paris: Musée D'Art Moderne de La Ville de Paris.

*Vũ Ánh. (2014). Thung Lũng Tủ Thần. Westminster, CA: Người Việt Books.

Vũ, Howard. (2004). Chay Trong Cỏ Cao - Running in Tall Grasses (Bilingual Script and Short film) (Unpublished master's thesis in films). University of Southern California, Los Angeles, CA.

Vương, Ocean. (2010). Burnings. Poetry Chapbook. Sibling Rivalry Press.

Vương, Ocean. (2013). No. Poetry Chapbook. YesYes Books. 


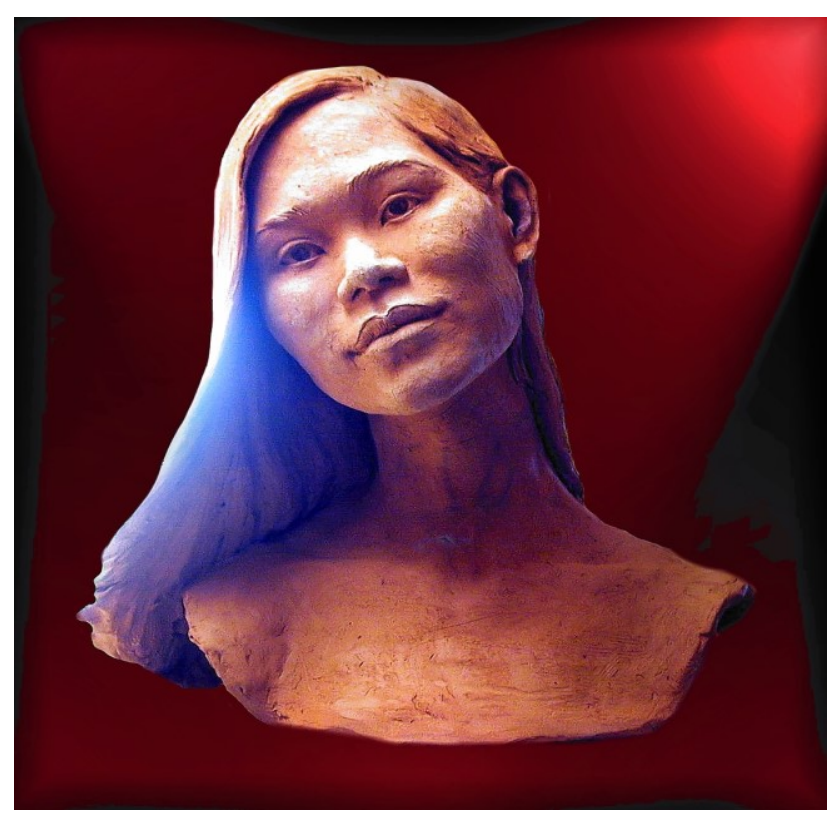

An award-winning and multilingual researcher, Trangdai Glassey-Tranguyen is the sole scholar having conducted hundreds of oral history interviews and multi-sited research on the Vietnamese diasporas in the U.S., Europe, Australia, and Asia since the 1990s. Trangdai is widely recognized for her advocacy, leadership, and community services. As the first scholar to conduct extensive ethnographic fieldwork and oral history projects in Little Saigon, Orange County, California, Trangdai received several awards for her studies. She won the 2004 CSU-system Student Research Competition, Graduate level in the Humanities, with the entry "Orange County, Yellow History: An Intimate Encounter with Vietnamese American Lives" based on the groundbreaking Vietnamese American Project. An exceptional-ranking Fulbright scholar, she started the very first ethnography and oral history project on the Vietnamese populations in Sweden in 2004 entitled "Home in Stockholm: Vietnamese Narratives of Transnationalism." Since 2004, Trangdai extended her fieldwork to ten other European countries to gain a panEuropean perspective about immigration and minority communities there. She initiated the Vietnamese Berlin Project in 2005 entitled, "Squatting in Racialized Berlin: Vietnamese Diasporic Subjectivity in a Climactic Double Division." Trangdai holds an M.A. in History from CSU Fullerton with two campus-wide outstanding awards, an M.A. in Anthropology from Stanford University with a thesis focusing on brokeraged Vietnamese brides, and is working toward her Ph.D.

A celebrated and syndicated bilingual author, Trangdai has published over 800 poetic, creative, translation, and critical works in/as academic journals, K-12 texts, anthologies, edited volumes, and the media worldwide. She has authored five books of bilingual poetry, and her poems have been translated into thirteen languages. Trangdai has taught, researched, published, and presented in Vietnamese and English on topics and in programs pertaining to the Vietnamese language, culture, and diasporas for the last twenty years at K-12 and university levels. In the last four years, she has diligently advocated for dual immersion Vietnamese-English education in public schools, and has served as a bicultural bilingual consultant for biliteracy programs. In early 2015, she published over 50 Vietnamese texts with audio recordings for Kindergarten and first grade levels with NRCAL at CSU Fullerton. 


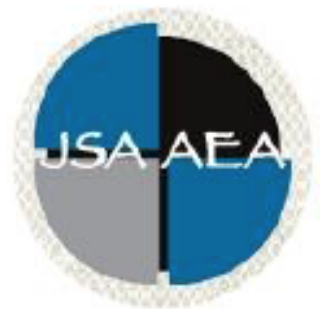

Volume 10 (2015)

\section{Journal of Southeast Asian American}

\section{Education and Advancement www.JSAAEA.org}

\section{Editor}

Dr. Wayne E. Wright

Purdue University

\section{Associate Editors}

Dr. Chhany Sak-Humphry

University of Hawaii at Manoa

Dr. Phitsamay Sychitkokhong Uy

University of Massachusetts, Lowell

\section{Book Review Editor}

Dr. Vichet Chhuon

University of Minnesota

\section{Creative Works Editor \\ Bryan Thao Worra \\ Lao Assistance Center}

\section{Journal Manager \\ Marshall Klassen \\ Purdue University}

\section{Editorial Review Board}

Dr. Steve Arounsack

California State University, Stanislaus

Dr. Sovicheth Boun

The State University of New York at Fredonia

Dr. George Chigas

University of Massachusetts, Lowell

Dr. Hien Duc Do

San Jose State University

Dr. Sophal Ear

Occidental College

Dr. Jeremy Hein

University of Wisconsin, Eau Claire

Dr. Nancy H. Hornberger

University of Pennsylvania

Dr. Peter Nien-Chu Kiang

University of Massachusetts, Boston
Dr. Carl L. Bankston III

Tulane University

Dr. Phala Chea

Lowell Public Schools

Dr. Loan Dao

University of Massachusetts, Boston

Dr. Changming Duan

University of Missouri, Kansas City

Dr. Sothy Eng

Lehigh University

Dr. Vincent K. Her

University of Wisconsin, Eau Claire

Dr. Peter Tan Keo

New York University

Dr. Kevin K. Kumashiro

University of San Francisco

Journal of Southeast Asian American Education \& Advancement, Vol. 10 (2015) 


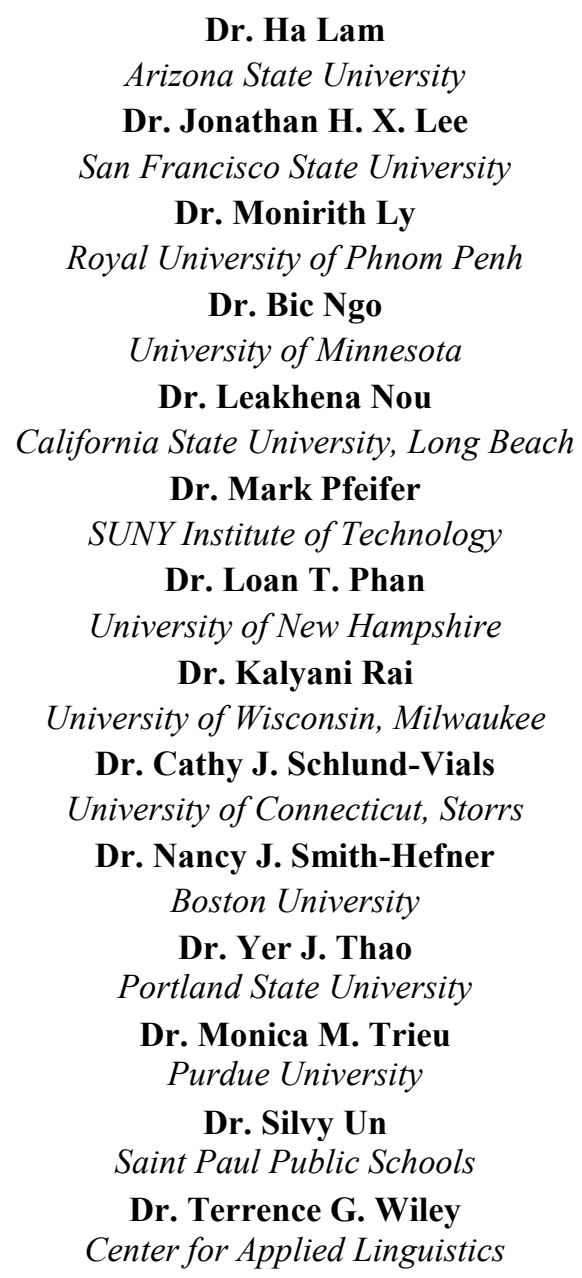

Dr. Ha Lam

Arizona State University

Dr. Jonathan H. X. Lee

San Francisco State University

Dr. Monirith Ly

Royal University of Phnom Penh

Dr. Bic Ngo

University of Minnesota

Dr. Leakhena Nou

California State University, Long Beach

Dr. Mark Pfeifer

SUNY Institute of Technology

Dr. Loan T. Phan

University of New Hampshire

Dr. Kalyani Rai

University of Wisconsin, Milwaukee

Dr. Cathy J. Schlund-Vials

University of Connecticut, Storrs

Dr. Nancy J. Smith-Hefner

Boston University

Dr. Yer J. Thao

Portland State University

Dr. Monica M. Trieu

Purdue University

Dr. Silvy Un

Saint Paul Public Schools

Dr. Terrence G. Wiley

Center for Applied Linguistics

\author{
Dr. Ravy Lao \\ California State University, Los Angeles \\ Dr. Stacey Lee \\ University of Wisconsin, Madison \\ Dr. Sue Needham \\ California State University, Dominguez Hills \\ Dr. Max Niedzwiecki \\ Daylight Consulting Group \\ Dr. Clara Park \\ California State University, Northridge \\ Dr. Giang Pham \\ University of Massachusetts \\ Dr. Karen Quintiliani \\ California State University, Long Beach \\ Dr. Angela Reyes \\ Hunter College, The City University of New York \\ Dr. Fay Shin \\ California State University, Long Beach \\ Dr. Christine Su \\ Ohio University \\ Dr. Alisia Tran \\ Arizona State University \\ Dr. Khatharya Um \\ University of California, Berkeley \\ Dr. Linda Trinh Vo \\ University of California, Irvine \\ Dr. Yang Sao Xiong \\ University of Wisconsin-Madison
}

Dr. Zha Blong Xiong

University of Minnesota

\section{Doctoral Student Editorial Review Board}

\author{
Virak Chan \\ University of Texas at San Antonio \\ Annie BichLoan Duong \\ San Joaquin County Office of Education \\ Hoa Nha Nguyen \\ Boston College \\ Malaphone Phommasa \\ Marshall University \\ Molly Wiebie \\ The University of Texas at Austin
}

\author{
Keo Chea-Young \\ University of Pennsylvania \\ Dung Minh Mao \\ University of Minnesota \\ Thien-Huong Ninh \\ University of Southern California \\ Krissyvan Truong \\ Claremont Graduate University \\ Soua Xiong \\ San Diego State University \& \\ Claremont Graduate University
}

Anna H. Yang

University of Georgia

Journal of Southeast Asian American Education \& Advancement, Vol. 10 (2015) 